\title{
Ad-Dressing Stem Cells: Hydrogels for Encapsulation
}

\author{
Leonidas Kandilogiannakis ${ }^{1}$, Eirini Filidou ${ }^{1}\left[\mathbb{D}\right.$, George Kolios ${ }^{1, *} \mathbb{C}$ and Vasilis Paspaliaris ${ }^{2}$ \\ 1 Laboratory of Pharmacology, Faculty of Medicine, Democritus University of Thrace, Dragana, \\ 68100 Alexandroupolis, Greece; lkandilo@med.duth.gr (L.K.); efilidou@hotmail.com (E.F.) \\ 2 Tithon Biotech Inc., San Diego, CA 92127, USA; bpaspa@tithonbiotech.com \\ * Correspondence: gkolios@med.duth.gr; Tel.: +30-25510-30368
}

\begin{abstract}
Regenerative medicine is a novel scientific field that employs the use of stem cells as cell-based therapy for the regeneration and functional restoration of damaged tissues and organs. Stem cells bear characteristics such as the capacity for self-renewal and differentiation towards specific lineages and, therefore, serve as a backup reservoir in case of tissue injuries. Therapeutically, they can be autologously or allogeneically transplanted for tissue regeneration; however, allogeneic stem cell transplantation can provoke host immune responses leading to a host-versustransplant reaction. A probable solution to this problem is stem cell encapsulation, a technique that utilizes various biomaterials for the creation of a semi-permeable membrane that encases the stem cells. Stem cell encapsulation can be accomplished by employing a great variety of natural and/or synthetic hydrogels and offers many benefits in regenerative medicine, including protection from the host's immune system and mechanical stress, improved cell viability, proliferation and differentiation, cryopreservation and controlled and continuous delivery of the stem-cell-secreted therapeutic agents. Here, in this review, we report and discuss almost all natural and synthetic hydrogels used in stem cell encapsulation, along with the benefits that these materials, alone or in combination, could offer to cell therapy through functional cell encapsulation.
\end{abstract}

Keywords: stem cells; encapsulation; biomaterials; hydrogels

check for updates

Citation: Kandilogiannakis, L.; Filidou, E.; Kolios, G.; Paspaliaris, V. AdDressing Stem Cells: Hydrogels for Encapsulation. Processes 2021, 9, 11. https://dx.doi.org/10.3390/pr9010011

Received: 25 November 2020 Accepted: 22 December 2020 Published: 23 December 2020

Publisher's Note: MDPI stays neutral with regard to jurisdictional claims in published maps and institutional affiliations.

Copyright: () 2020 by the authors. Licensee MDPI, Basel, Switzerland. This article is an open access article distributed under the terms and conditions of the Creative Commons Attribution (CC BY) license (https: / / creativecommons.org/ licenses/by/4.0/).

\section{Introduction}

Over the last few decades, cell-based therapies have been a novel therapeutic approach for several diseases. Various types of stem cells have been used in experimental models and clinical trials for the regeneration and functional restoration of specific damaged tissues and organs, and they have been proposed to have a central role in regenerative medicine $[1,2]$. These cells are characterized by their capacity for self-renewal and differentiation into specific cell types of all tissues and organ systems of the body, according to the microenvironmental conditions, preserving the damage repair ability in the host $[3,4]$. The transplantation of exogenous stem cells for the induction of tissue regeneration could be autologous and/or allogeneic (non-autologous) [2,5]. In cases of allogeneic stem cell administration, graft-versus-host disease is expected to occur and appropriate measures must be taken, as stem cells express the major histocompatibility complex (MHC) receptor and secrete soluble mediators for inviting immune cells and enabling this type of reaction $[6,7]$. For avoiding the consequences of host-versus-transplant reactions, cell-based therapeutic approaches, with the support of engineering technologies, have been developing new techniques that combine principles of material science and engineering with stem cell biology [8]. Cell immobilization techniques have been developed during the last few decades to provide several advantages, such as structural support and a controlled environment, to cells [9]. These techniques can be divided into two major categories, the entrapment of cells into scaffolds (cell-laden scaffolds) and the encapsulation of cells into hydrogels. Scaffolding technology includes a great variety of materials (including hydrogels) aiming to provide 
appropriate vehicles for cell seeding, while encapsulation is oriented towards micro-tuning specific hydrogels, creating cell-incorporated, semi-permeable "capsules" [10].

Encapsulation provides a semi-permeable barrier surrounding the cell, which, on the one hand, impedes the recognition of the implanted cell by the host's immune system and its subsequent elimination and, on the other hand, allows the encapsulated cell to have access to nutrients and to maintain its functional potential, mainly through the secretion of soluble mediators that help in repairing the target tissue (Figure 1) [11].

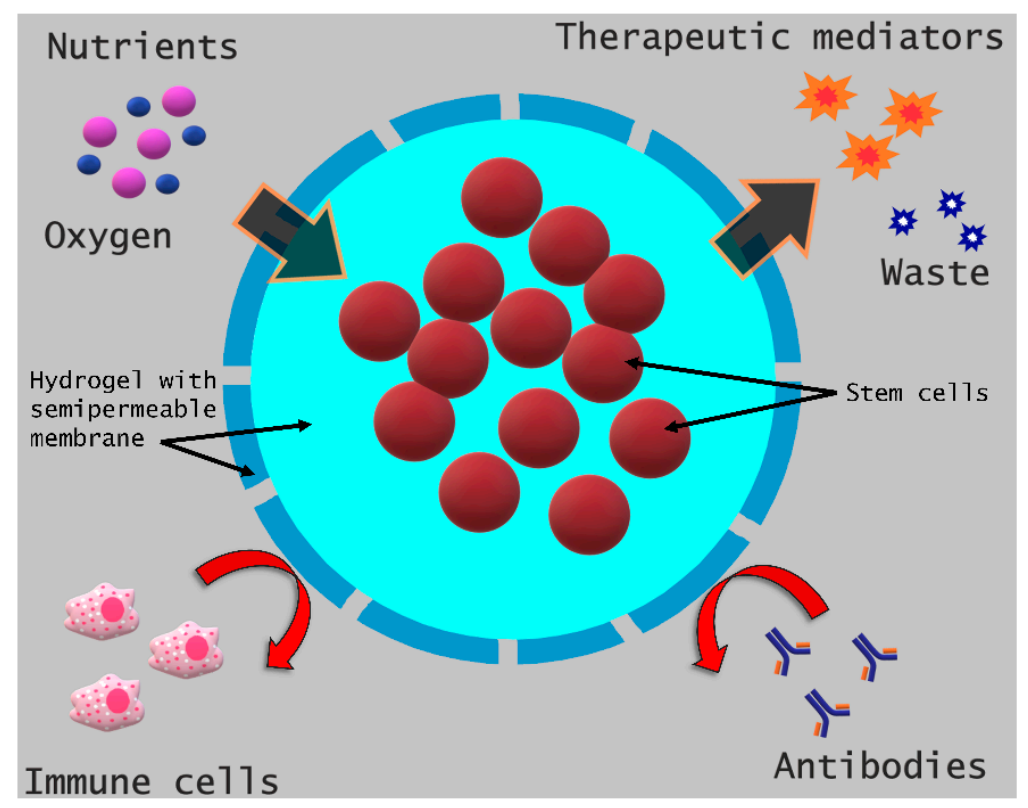

Figure 1. Schematic of stem cell encapsulation and its benefits.

Since 1964, when Chang first presented cell encapsulation technology [12], a large number of cell encapsulation biomaterials have been used and proposed for a variety of diseases and pathologies $[8,13,14]$. The physicochemical properties of biomaterials appear to play an important role, thus dictating which ones should be utilized in specific applications in order to achieve optimized results in regenerative medicine interventions (Table 1).

To date, several types of cells and stem cells (Table 2) have been used in encapsulation technology in various diseases; it is understood that different materials and techniques need to be developed in order to ensure the benefits of encapsulation in any case [14].

The methodology, and particularly the physicochemical properties of the biomaterial that creates the cell envelope, are important for providing the appropriate niche, thus maintaining cell protection without losing the functional properties and benefits for cell therapy. There is a great variety of encapsulation techniques and gelation processes (Table 3) that have been thoroughly discussed in previous articles [54-57].

Table 1. Natural and synthetic encapsulation biomaterials utilized in various medical applications.

\begin{tabular}{cc}
\hline Application & Biomaterial \\
\hline Angiogenesis & Gelan gum-HA [15], Alginate-Gelatin [16], PEG [17], HA-MAP [18] \\
\hline Bone tissue engineering & Alginate [19], GelMA [20], Alginate-g-PNIPAAm [21], Collagen-Fibrin [22] \\
\hline Breast cancer & Alginate [23] \\
\hline Cartilage tissue engineering & CS-MA-PEGDA [24], CH-GP-HEC [25], PEG-PNIPAAm [26], Gelatin-HA [27] \\
\hline Cartilage/bone tissue engineering & Poloxamer 407 [28], Gelatin-Methacrylamide [29] \\
\hline Diabetes & PPS-b-PDMA-b-PNIPAAm [30]
\end{tabular}


Table 1. Cont.

\begin{tabular}{cc}
\hline Application & Biomaterial \\
\hline Foreign body response & Alginate [31] \\
\hline Ischemic stroke & CS-bFGF [32] \\
\hline Ischemic tissue engineering & PNIPAAm-PHEMA-AOLA-PEGMA-PFO [33] \\
\hline Muscle tissue engineering & PNIPAAm [35], PNIPAAm-PPAA-PHEMA-OTMC-PEGMA [36], PNIPAAm-PAA [37], \\
Myocardial infarction & PEG-fibrinogen [38], PNIPAAm-SWCNTs [39], HA-MAP [40] \\
\hline Neural and visual repairment & Alginate (Ultra high viscous) [42] \\
\hline Sensorineural hearing loss & Alginate-Collagen [47], CS-MA [48] \\
\hline Spine injury & PEGDA [49], Poloxamer 407-SAP [50] \\
\hline Wound healing (skin) & Poloxamer 407 [51] \\
\hline Wound healing (diabetes) & Alginate [52] \\
\hline Wound healing (corneal) & PEG-4MAL-IFN- $\gamma$ [53]
\end{tabular}

AOLA: acrylate-oligolactide; APMA: N-(3-Aminopropyl)methacrylamide; b: block; bFGF: basic fibroblast growth factor; $\mathrm{CH}$ : chitosan; CS: chondroitin sulfate; g: graft; GelMA: gelatin methacrylate; GP: glycerophosphate; HA: hyaluronic acid; HEC: hydroxyethyl cellulose; IFN- $\gamma$ : interferon gamma; L: laponite; MA: methacrylate; MAP: mussel adhesive protein; OTMC: oligo(trimethylene carbonate); PAMAM: polyamidoamine; PDMA: poly(dimethylacrylamide); PEG: poly(ethylene glycol); PEGDA: poly(ethylene glycol) diacrylate; PEGMA: methacrylate-poly(ethylene glycol); PFO: perfluorooctane; PHEMA: poly(2-hydroxyethyl methacrylate); PNIPAAm: poly(Nisopropylacrylamide); PPAA: polypropylacrylic acid; PPS: poly[(propylene sulfide; SAP: sodium ascorbyl phosphate; SWCNTs: single-wall carbon nanotubes; 4MAL: four-arm maleimide.

Table 2. Natural and synthetic biomaterials utilized for the encapsulation of different types of stem cells.

\begin{tabular}{cc}
\hline Stem Cell Type & Biomaterial \\
& Collagen-Fibrin [22], CH-GP-HEC [25], PHEMA-APMA-PAMAM [45], \\
Mesenchymal stem cells & L-PDMA-PNIPAAm [46], PEG-PNIPAAm [26], Alginate [23], \\
& $\begin{array}{c}\text { PEGD [49], Fibrin [34], Gelatin-HA [27], PPS-b-PDMA-b-PNIPAAm } \\
\text { [30], Alginate-Gelatin [16], PEG-4MAL-IFN- } \gamma \text { [53], HA-MAP [18,40] }\end{array}$ \\
\hline Bone marrow mesenchymal stem cells & PNIPAAm-PHEMA-AOLA-PEGMA-PFO [33], CS-MA-PEGDA [24], \\
Alginate-g-PNIPAAm [21]
\end{tabular}

Brain-derived neurotrophic factor-producing mesenchymal stem cells

Alginate (ultrahigh viscous) [42]

Adipose-derived stem cells

Gelan gum-HA [15], Poloxamer 407 [51], Gelan gum [43], PNIPAAm-SWCNTs [39], Alginate [19], PEG [17]

Telomerase-immortalized human adipose-derived stem cells

Gelatin-Methacrylamide [29]

Cardiosphere-derived cells

PNIPAAm [35], PNIPAAm-PPAA-PHEMA-OTMC-PEGMA [36]

Human cardiac stem cells

PNIPAAm-PAA [37]

Neural stem cells-dental pulp stem cells

Alginate-Collagen [47], CS-MA [48]

Induced pluripotent stem cell-derived neural progenitor cells

CS-bFGF [32]

Human embryonic stem cell derived-neural stem cells

HA [44]

Retinal stem cell-derived rods and neural stem and progenitor cells

HA and methylecelluse [41] 
Table 2. Cont.

\begin{tabular}{cc}
\hline Stem Cell Type & Biomaterial \\
\hline Dental pulp stem cells & Poloxamer 407 [28] \\
\hline Human placenta-derived mesenchymal stem cells & Alginate [31] \\
\hline Multipotent adult progenitor cells & Alginate [52] \\
\hline Mouse embryonic stem cells & PEG-fibrinogen [38] \\
\hline
\end{tabular}

AOLA: acrylate-oligolactide; APMA: N-(3-Aminopropyl)methacrylamide; b: block; bFGF: basic fibroblast growth factor; BMP-2: Bone morphogenetic protein 2; CH: chitosan; CS: chondroitin sulfate; g: graft; GelMA: gelatin methacrylate; GP: glycerophosphate; HA: hyaluronic acid; HEC: hydroxyethyl cellulose; IFN- $\gamma$ : interferon gamma; L: laponite; MA: methacrylate; MAP: mussel adhesive protein; OTMC: oligo(trimethylene carbonate); PAMAM: polyamidoamine; PDMA: poly(dimethylacrylamide); PEG: poly(ethylene glycol); PEGDA: poly(ethylene glycol) diacrylate; PEGMA: methacrylate-poly(ethylene glycol); PFO: perfluorooctane; PHEMA: poly(2-hydroxyethyl methacrylate); PNIPAAm: poly(N-isopropylacrylamide); PPAA: polypropylacrylic acid; PPS: poly[(propylene sulfide; SAP: sodium ascorbyl phosphate; SWCNTs: single-wall carbon nanotubes; 4MAL: four-arm maleimide.

Table 3. Key encapsulation and gelation methodologies.

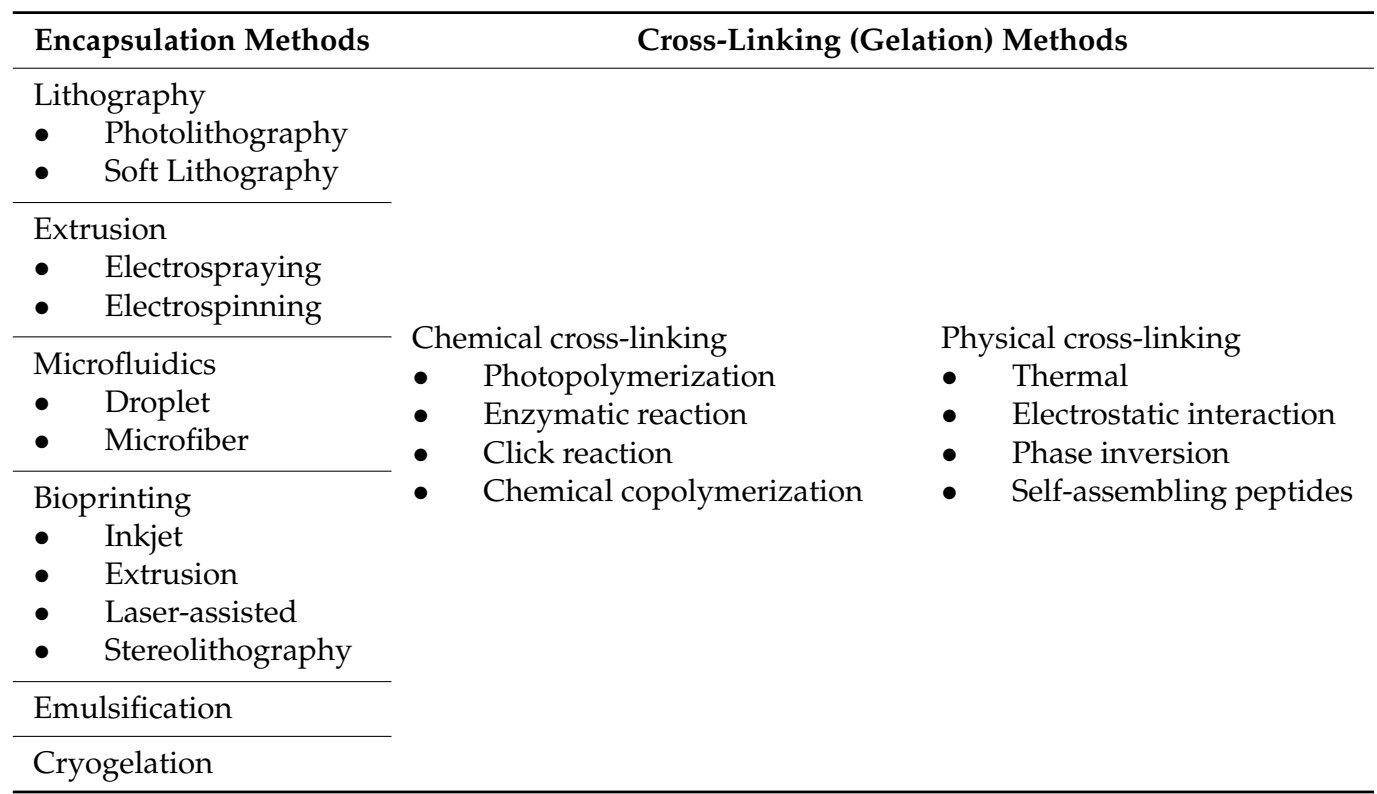

Encapsulation technology has greatly advanced due to the parallel advancement of material and microfluidics science, giving rise to microencapsulation that can allow even single-cell encapsulation [58], thus practically giving the opportunity to "dress up" individually the stem cells depending on the application.

In this review, we will focus on the different types of hydrogels used in stem cell encapsulation technology, as well as analyzing the benefits of stem cell encapsulation in tissue engineering and regenerative medicine.

\section{Hydrogels}

Hydrogels are materials that swell in water while retaining a substantial fraction of water within their structures [59]. They were first reported in 1960, by Wichterle and Lim, in their study of poly(2-hydroxyethyl methacrylate) (PHEMA) gel, which is used even today in soft contact lenses [60,61]. Since then, hydrogels have been widely studied and used in a great variety of biomedical applications [62], due to their close resemblance to natural living tissue. High water content, convenient porosity and soft structure are properties of hydrogels that enable them to simulate the physical characteristics of the extracellular matrix (ECM) more closely than any other class of synthetic biomaterials [63].

Hydrogels are formed by the cross-linking of polymer chains through either physical or chemical means and can be made of naturally occurring polymers, such as collagen or chitosan, or synthetic polymers like polyethylene glycol (PEG) (Figure 2) [64]. 
A

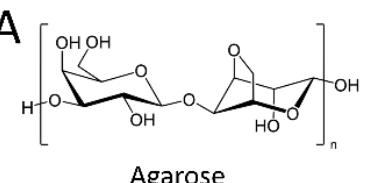
Agarose

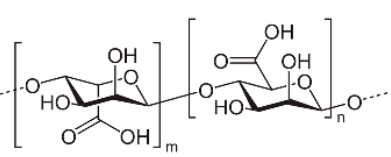

Alginate

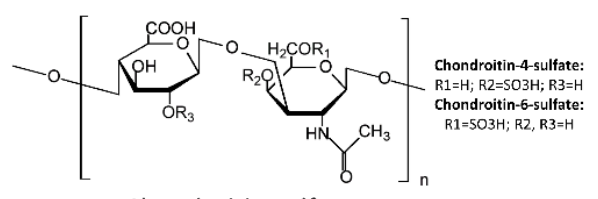

Chondroitin sulfate

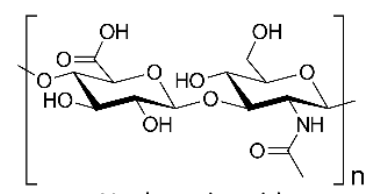

Hyaluronic acid
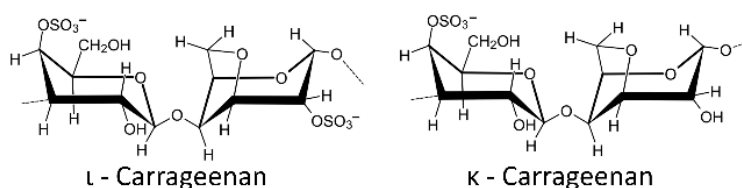

K - Carrageenan

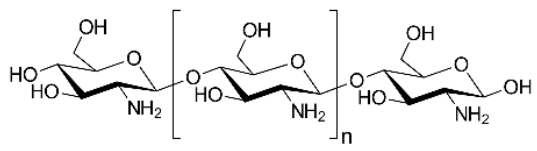

Chitosan

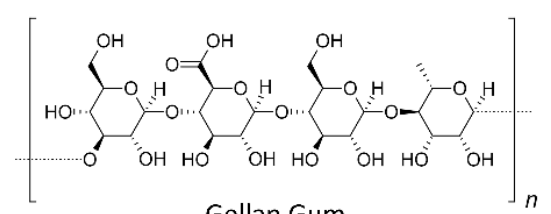

Gellan Gum

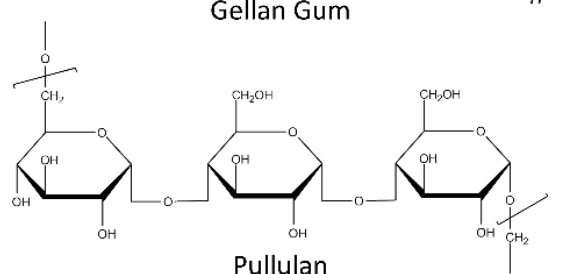

B

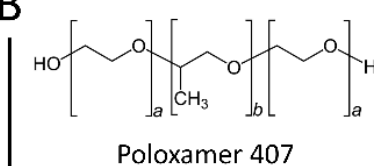

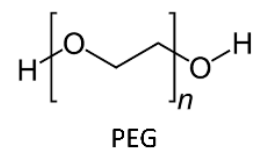<smiles>CCC(C)O</smiles>

PVA<smiles>CC(C)NC(=O)C(C(C)C)C(C)(C)C</smiles>

Figure 2. Chemical structures of natural (A) and synthetic (B) hydrogels.

The low interfacial tension between the hydrogels and the environmental fluids results in a low protein adsorption rate and cell adhesion, making them highly biocompatible. Moreover, the plasticity of hydrogels reduces the mechanical irritation on the surrounding area and provides a high degree of permeability to nutrients and metabolites [65]. There are many different ways that hydrogels may be classified, based on the polymer source, the polymeric composition, the type of cross-linking, their configuration or physical appearance [66]. In this review, hydrogels are categorized based on their origin.

\subsection{Natural Hydrogels}

\subsubsection{Polysaccharides}

Agarose

Agarose is a linear polymer consisting of repeating units of agarobiose, a disaccharide made up of D-galactose and 3,6-anhydro-L-galactopyranose, and it is extracted from the cell wall of a group of red algae (Rhodophyceae) [67].

In 2004, agarose was first used in stem cell encapsulation and proved to be a promising biomaterial, as stem cells could remain alive throughout the process and could differentiate into hematopoietic progenitors [68]. Since then, agarose has been used in numerous stem cell encapsulation studies, either alone or in combination with extracellular matrix proteins, such as collagen and fibrin. Batorsky et al. encapsulated human mesenchymal stem cells (hMSCs) in collagen-agarose and reported that cell viability remained high and their differentiation capacity was regulated by the collagen concentration; the higher its concentration, the greater the differentiation capacity towards the osteogenic lineage [69]. On the other hand, Sakai et al. used agarose alone as an encapsulation stem cell material and showed once again that agarose could permit stem cell proliferation and differentiation [70]. Finally, in a recent study, Benavente-Babace et al. studied the egress of therapeutically relevant cells, such as hMSCs, using a microfluidic device to produce monodisperse agarose microcapsules and concluded that agarose can be an excellent candidate for the encapsulation and delivery of mesenchymal stem cells (MSCs) in cell-based strategies of tissue regeneration [71]. 
Alginate

Alginate is an unbranched heteropolysaccharide of $1-4$ glycosidically linked $\beta$-DMannuronic (M) and $\alpha$-L-Guluronic (G) acids in varying composition and sequences, distributed widely in the cell walls of brown algae. In aqueous solutions and in the presence of divalent cations, such as $\mathrm{Ca}^{2+}$, they form gels through ionic cross-linking.

When it comes to stem cell encapsulation using alginate as a starting biomaterial, it is preferable not to use it alone but in combination with other polymers. Alginate alone forms dense hydrogels, it has low biodegradability and high stiffness and it blocks cellular growth due to the lack of cell adhesion molecules [72]. Rezaei et al. compared alginate-gelatin and alginate-alone hydrogels and found that the MSC growth rate was significantly greater in the mixed hydrogels [73]. For the same reason, Steiner et al. also used alginate-gelatin hydrogels for the encapsulation of MSCs and showed that not only the cell viability was unaltered but also that these scaffolds could promote angiogenesis in an in vivo model [16]. Nonetheless, alginate alone seems to have some positive effects, depending on the application. For instance, Al-Jaibaji et al. showed that the encapsulation of multipotent adult progenitor cells in alginate hydrogels could induce a wound-healing reaction in corneal stromal cells, through the secretion of soluble factors by the progenitor cells [52].

\section{Carrageenan}

Carrageenan is a sulfated polysaccharide that is extracted from red marine algae and it is comprised of either repeating disaccharide units of 4-linked $\beta$-D-galactopyranose (Gunit) and $\alpha$-D-galactopyranose or 4-linked 3,6-anhydrogalactose, with a variable portion of sulfalite groups. According to the position and number of sulfate groups, carrageenans are divided into three families: $\kappa, l$, and $\lambda$, corresponding to one, two, and three sulfate groups per disaccharide. In aqueous solutions and in the presence of cations, both $\mathrm{k}$ - and t-carrageenans easily form, on cooling, thermo-reversible gels [74,75].

Regarding carrageenan, there is only one reference in the literature in which it is used for mesenchymal stem cell encapsulation. In this study, Thakur et al. reported that upon encapsulation, stem cell viability remained high, no alterations in cell morphology, spreading and metabolic activities were observed and this biomaterial could be used for cartilage regeneration [76].

\section{Chitosan}

Chitosan is a natural, non-toxic, semi-crystalline, cationic polysaccharide with biocompatibility and structure similar to that of glycosaminoglycans. It is obtained industrially by hydrolyzing the amino-acetyl groups of chitin (primary component of cell walls in fungi, the exoskeletons of arthropods, such as crustaceans and insects, the radulae of mollusks, cephalopod beaks and the scales of fish and lissamphibians) by an alkaline treatment [77].

Due to its similarity to glycosaminoglycans, chitosan-based hydrogels are widely used in cartilage tissue engineering [78-80]. Naderi-Meshkin et al. showed that the encapsulation of MSCs in chitosan-based hydrogel could sustain cell viability and could promote differentiation towards the chondrogenic pathway [25]. Chitosan is also used in combination with other biomaterials, such as hyaluronan, and it has been shown that this combination can support cell viability, proliferation of adipose-derived stem cells and it can be a good candidate for tissue engineering [81].

\section{Chondroitin Sulfate (CS)}

CS is a sulfated glycosaminoglycan composed of chains of unbranched polysaccharides of variable length containing two alternating monosaccharides: D-glucuronic acid and $\mathrm{N}$-acetyl-D-galactosamine. It is usually found attached to proteins as part of a proteoglycan. A chondroitin chain can have over 100 individual sugars, each of which can be sulfated in variable positions and quantities; chondroitin 4-sulfate (C4S or CSA) and chondroitin 6-sulfate (C6S or CSC) are two of the most common forms [82]. CS is an impor- 
tant structural component of cartilage and provides much of its resistance to compression. There are a number of different sources of CS; in the nutraceutical market, the main sources are bovine, shark and porcine cartilage [83].

CS has been proven to be a good candidate for applications that include neural stem cells. Karumbaiah L et al. used hydrogels containing CS for the encapsulation of neural stem cells and found that this biomaterial could regulate stem cell self-renewal and could highly absorb significant factors for the survival of neural stem cells [84]. Similarly, Liu C et al. observed that CS is a promising biomaterial for the treatment of spinal cord injuries, as it favors neural stem cells to differentiate into neurons, while at the same time, it inhibits astrocyte development, an unwanted side effect during the process of neural stem cell differentiation [48].

\section{Gellan Gum}

Gellan gum is an anionic heteropolysaccharide secreted by the bacteria Sphingomonas elodea (formerly Pseudomonas elodea) [85]. It is composed by tetrasaccharide repeating units consisting of 1,4- $\alpha$-L-rahmnose, $1,3-\beta$-D-glucose, $1,4-\beta$-D-glucuronic acid and 1,4- $\beta$ D-glucose [86].

Although not widely used, there are a few references to its application in stem cell encapsulation. Cerqueira et al. used gellan gum-based hydrogel to encapsulate adiposederived stem cells (ADSCs) and microvascular endothelial cells and they showed that this structure could promote wound healing and angiogenesis in an in vivo model [15]. In the same manner, Gomes et al. encapsulated in gellan gum-based hydrogel two different types of cells, ADSCs and olfactory ensheathing cells, and showed an increased in vitro growth rate and great motor improvements in an in vivo model of spinal cord injury [43]. Additionally, modified gellan gum-based hydrogels have shown promising results, again, in the field of neural tissue engineering [87].

\section{Hyaluronic Acid}

Hyaluronic acid (HA) is a relatively simple glycosaminoglycan present in mammals, characterized by repeating disaccharide units made up of $1,4-\beta$-D-glucuronic acid and 1,3- $\beta$-N-acetyl-D-glucosamine [88].

HA is naturally found in soft tissues, such as the cartilage [89], and thus, previous studies have shown that it can successfully support chondrogenesis using MSCs [27,90,91]. Apart from its use in soft tissue engineering, HA has been also used in other systems. Ballios et al. reported that hyaluronan-based hydrogel could promote retinal stem cell survival in the retina, through interactions between the hydrogel and the stem cells, significantly improve visual function and the neural stem and progenitor cell state [41]. In addition, HA has been also used in combination with growth factors that promote stem cell differentiation, offering a useful tool for the in situ differentiation of pluripotent stem cells $[41,92]$.

Pullulan

Pullulan is an extracellular and unbranched water-soluble homopolysaccharide, consisting of a-(1-6) linkages of a-(1-4)-linked maltotriose units, and is secreted primarily by strains of the fungus Aureobasidium pullulans. Due to its unique linkage pattern, pullulan has distinctive physical traits, such as structural flexibility and solubility; unlike other polysaccharides, it has great film and fiber forming capabilities that resemble those of synthetic polymers. It is biodegradable and highly water-soluble in its underivatized form $[83,93,94]$.

Although pullulan is widely used in other applications, but not so far for stem cell encapsulation, a recent study investigated its properties and showed that it could be a good candidate for stem cell encapsulation [95]. 


\subsubsection{Proteins}

Collagen

Collagen is the major component of the extracellular matrix of connective tissues and it is responsible for their structure and functions. The collagen family consists of 28 distinct types that are distinguished by Roman numbers (I-XXVIII), following the chronological order of their discovery. All collagens are trimers, consisting of at least one stiff, rod-like domain of varying length, called collagenous domains and non-collagenous domains. The number and structure of these domains depend on the specific type of collagen [96].

Collagen is composed of a triple helix, having a divergent protein composition, mainly due to its high hydroxyproline content. It can be extracted from a variety of sources; it offers low immunogenicity, good permeability, biocompatibility and biodegradability, but relatively modest mechanical properties. To overcome this problem, various practices are employed, such as cross-linking by chemical or physical means and modifications with other polymers or inorganic materials [97].

Injectable collagen-phenolic hydroxyl hydrogels, capable of controlling a wide range of physicochemical properties, such as stiffness and degradability, were tested on the formation of vascularized engineered tissue graft by bone marrow-derived mesenchymal stem cells (BMSCs) in vivo. The results were promising as the hydrogel not only improved the long-term differentiation of the transplanted BMSCs into osteoblasts but also increased the number of adipocytes inside the vascularized engineered tissue after one month of implantation in a mouse [98].

Using a novel microfluidic device to encapsulate neural stem cells and dental pulp stem cells within an alginate-collagen hydrogel resulted in the survival of both cell types for up to three weeks in culture. Moreover, it was observed that the stem cells preserved their multipotency upon selective release from the microcapsules [47].

Elastin

Elastin is a highly elastic mammalian protein found in connective tissue that possesses the ability to resume the initial shape after the use of stretching or contracting mechanical force. It is rich in hydrophobic amino acids such as glycine and proline, which form mobile hydrophobic regions bounded by cross-links between lysine residues [99]. Elastin-based biomaterials are suitable for repairing elastic tissues, as they can improve local elasticity and support cellular interaction and signaling. Several studies that combine elastin hydrogels with MSCs have demonstrated their ability to also regenerate non-elastic tissue [100].

MSCs differentiation can be controlled by their immediate environment as it has been proven that tissue elasticity can influence their inclination towards specific lineages and phenotypes, thus making elastin hydrogels an ideal stem cell encapsulation candidate for specific applications [101]. Due to the growing accessibility of the elastin precursor, tropoelastin, there is increased research interest in stem cell encapsulation using elastinbased hydrogels [102].

\section{Elastin-Like Protein and Hyaluronic Acid}

The major limitation of HA hydrogels is the increased mechanical stiffness which is observed when there is also an increase in the concentration of HA $[91,103,104]$. This obstacle has been overcome by combining HA with elastin-like protein (ELP). Zhu et al. combined ELP with HA and created a new hydrogel for the encapsulation of bovine chondrocytes. They found that the mechanical stiffness of this biomaterial remained unchanged, even if the concentration of HA was altered. In addition, they observed that HA in varying concentrations could affect the proliferation rate of chondrocytes, their expression signatures and, ultimately, their differentiation fate. Zhu et al. concluded that the ELP-HA combination could enable the creation of soft hydrogels, ideal for chondrocyte proliferation and cartilage differentiation [105]. In another study by the same research team, it was shown that the ELP-HA combination could protect encapsulated MSCs from shredding when passed through a needle. It could also be rapidly reformed into its original 
shape, enabling MSCs to be homogenously dispersed into a 3D environment. In addition, they observed that this new biomaterial could enhance the survival of MSCs and prolong their culturing even up to three weeks after the injection. Finally, they reported that the differentiational capacity of encapsulated MSCs remained unaltered, suggesting that ELP-HA hydrogels might be excellent candidates for stem cell transplantations and tissue regeneration [106].

Fibrin

Fibrin monomers are naturally produced during the degradation of fibrinogen by the thrombin protease; they then polymerize and ultimately form fibrin networks with the help of other coagulation factors to prevent blood loss [102]. Fibrin, apart from its essential role in blood clot formation, is also used in the field of stem cell bioengineering. Lalegül-Ülker Ö et al. found that the encapsulation of MSCs in fibrin microbeads and their administration in rats could greatly regenerate muscle tissue injuries [34]. Fibrin-based hydrogels have been also found to be good candidates for the development of bone formation from MSCs. Heo DN et al. found that the encapsulation of MSCs in fibrin-based hydrogels and their supplementation with endothelial cells could further promote bone tissue formation [22]. These studies suggest that fibrin is a promising biomaterial in the field of muscle and bone tissue regeneration using MSCs.

Gelatin

Gelatin is a protein that is obtained when collagen is disintegrated into smaller parts through hydrolytic degradation. At temperatures exceeding $40{ }^{\circ} \mathrm{C}$, gelatins are soluble in water, but upon cooling, they form transparent gels. Since gelatin derives from collagen, a natural source found in many organisms, it possesses several advantages; it does not cause antigenicity, it can be totally degradable in vivo, and its physicochemical properties can be regulated. Another crucial benefit of gelatin is the fact that it is presented with many functional side groups that enable it to be chemically cross-linked with other compounds, such as drugs, thus making it an excellent candidate for a drug delivery vehicle. Nonetheless, gelatins are not stable in the human body due to their low melting point and, therefore, they need to be stabilized by chemical cross-linking prior to their use [107].

In a previous study, Tzouanas SN et al. found that the gelatin loading and size of the microparticles could regulate MSC viability; the smaller the loading and size, the greater cell viability. In addition, they found that the interaction between the MSCs and the gelatin microparticles could initiate the differentiation process towards the osteogenic lineage, making these microparticles excellent candidates for tissue engineering [108]. In the same manner, Aparnathi MK and Patel JS showed that biodegradable, methacrylated gelatin gel could serve as a great scaffold for ADSC encapsulation, as it would not affect the osteogenic capacity of the stem cells [109]. The potential of gelatin-based microparticles to be used in stem cell encapsulation has also been shown in a recent study, in which MSCs could retain their viability and differentiation capacity inside colloidal gelatin microgels [110]. Taken together, these findings show that gelatin is an excellent biomaterial for stem cell encapsulation, as it is nontoxic for stem cells and it may promote their differentiation.

Keratin

Keratin is not a single substance but rather a complex formation that includes several types of keratin, keratin filament-associated proteins and enzymes, and it is produced by epithelial cells. It is highly resistant to degradation by enzymes, such as pepsin and trypsin, insoluble in aqueous solutions and can be found in tissues such as skin, hair and nails [111]. Due to its resistance in degradation, keratin-based scaffolds seem promising in tissue engineering, as they are slowly degraded, while collagen-based hydrogels are easily degraded. Barati $\mathrm{D}$ et al. showed that the use of keratin hydrogels in encapsulating MSCs could promote their differentiation into osteogenic and chondrogenic lineages, with 
a similar efficiency as in gelatin-based hydrogel, while having the advantage of not being easily degraded, thus making them an excellent candidate for a delivery system [112].

\section{Silk Fibroin}

Fibroin is an insoluble protein present in silk, mainly produced by the larvae of Bombyx mori, with an amino acid composition primarily of glycine, alanine and serine. Silk is composed of $\beta$-sheet structures, permitting tight packing of stacked sheets, granting the strength and resilience of silk fibers. Silk fibroin fibers consist of two proteins (a light and heavy chain) linked by a single disulfide bond in a 1:1 ratio. These proteins are coated with a family of hydrophilic proteins called sericins that are removed during the silk fibroin isolation process. The unique features of silk (structure, biocompatibility, versatile morphologies, genetic modification, thermal stability and controllable degradation) classify it as a favorable biomaterial for various clinical applications [113].

In a recent study, Patil and Singh were the first to demonstrate that silk fibroin-alginate beads can be used to encapsulate hMSCs at various cell densities, using an innovative, cellcompatible cross-linking method that allows for simultaneous encapsulation. In addition, by including carboxyl and phosphate groups into the beads, they showed that that hMSCs were able to grow, proliferate and differentiate into osteogenic and chondrogenic lineages without the need for differentiation media [114]. In another recent study, Hasturk et al. fabricated silk fibroin-based hydrogels which were cross-linked with either tyraminesubstituted silk fibroin or gelatin; they then encapsulated hMSCs and found that these biomaterials could significantly improve the cell morphology and metabolic activity [115].

\subsection{Synthetic Hydrogels}

\subsubsection{Poloxamer 407}

Poloxamer 407-also known as Pluronic F127-is a synthetic hydrogel made of amphiphilic copolymers, consisting of approximately $70 \%$ by weight of ethylene oxide and $30 \%$ of polypropylene oxide. It is injectable and forms reversible gels, meaning that, by freezing the gel or by heating it above its liquefaction temperature, it transforms from the solid to liquid phase. The procedure of cooling or heating can be executed numerous times, changing its properties [116].

One of the first studies examining Poloxamer 407 as a potential hydrogel for stem cell encapsulation was that of Wagner et al. They found that Poloxamer 407 could serve as a good encapsulating material, as it protected mouse BMSCs from bursting during syringe needle injections [117]. These results were also confirmed by Diniz et al. In their study, they found that Poloxamer 407 could be a promising candidate for dental pulp and human BMSC (hBMSC) encapsulation, as it greatly supported cell proliferation, viability and the differentiation of stem cells towards osteogenic and adipogenic lineages [28]. In another study, Kaisang et al. investigated whether Poloxamer 407 would enable encapsulated ADSCs to promote wound healing during an in vivo model of diabetes. Indeed, Poloxamer 407 proved to be an excellent encapsulating biomaterial, as stem cells promoted angiogenesis and proliferation at the wound sites and greatly enhanced wound healing [51]. Finally, Choi et al. examined the encapsulation of rabbit BMSCs in a double network hydrogel consisting of Poloxamer 407-heparin copolymer and gellan gum both in vivo and in vitro and concluded that composite hydrogels are possible candidates for tissue engineering, as they maintained the cell morphology and viability [118].

\subsubsection{Polyethylene Glycol (PEG)}

One of the most widely used synthetic hydrogels in stem cell encapsulation is the PEG. It is a linear or branched, neutral polyether, produced from ethylene oxide by anionic polymerization in a variety of molecular weights, and it is soluble in water and most organic solvents [119]. PEG makes an excellent candidate for stem cell encapsulation, as it possesses unique properties, such as being hydrophilic, biocompatible, inactive, highly flexible and non-biofouling. It can also be modified to carry specific molecules that could enable better 
stem cell proliferation and differentiation. Photopolymerization is the basic technique for PEG gelation, and methacrylated PEG is used as a starting material. In addition, by changing the cross-linking density and/or combining PEG with other biomaterials, various synthetic PEG derivatives can be produced, such as (meth)acrylate, allyl ether, maleimide, N-hydroxysuccinimide (NHS) ester and others [120].

Li et al. manufactured a microgel consisting of gelatin norbornene and PEG and used it for the encapsulation of hBMSCs. They showed that the ratio 4:1 of gelatin norbornene and PEG had the best result regarding cell viability, and it was maintained at a relatively high level for a long culture period. In addition, hBMSC morphology remained unchanged over time and hBMSC differentiation towards chondrocytes was extremely successful, making this microgel an excellent candidate for stem cell culture and differentiation protocols [121]. In another study, Hunckler et al. investigated the mechanical, pharmacological and biological properties of 4-arm ester-linked and amide-linked PEG-norbornene (PEG$4 \mathrm{eNB}$ and PEG-4aNB) in rats. They found that replacing the ester linkage with the amide one could make hydrogels more stable and less degradable in vivo. In addition, they observed that the mechanical and pharmacological properties remained untouched and the cytocompatibility of PEG-4aNB with hMSCs was unaffected [122]. Cruz-Acuña et al., using another PEG derivative, the PEG-4MAL that has maleimide groups at each terminus, showed that it can be an excellent hydrogel material for the encapsulation of stem cells, their later differentiation into organoids and their transmission and engraftment into wounded colonic tissues of animal models [123].

\subsubsection{Poly(N-isopropylacrylamide) (PNIPAAm)}

PNIPAAm is a synthetic temperature-responsive polymer which demonstrates an interesting behavior, as it possesses inverse solubility upon heating, being transformed from a hydrophilic to a hydrophobic structure at temperatures between 30 and $35^{\circ} \mathrm{C}$ [124]. Thus, it has been widely used in a number of applications, including stem cell encapsulation. Niu et al. utilized PNIPAAm and the copolymers, which included acrylate-oligolactide (AOLA), poly(2-hydroxyethyl methacrylate) (PHEMA) and methacrylate-poly(ethylene glycol)-perfluorooctane (PEGMA-PFO), and encapsulated MSCs in order to investigate the biomaterials' properties in vitro and in vivo. They found that encapsulated MSCs survived and proliferated for a period of 14 days under hypoxia conditions, the degradation products of the hydrogels did not cause any cytotoxicity and the implantation of these biomaterials in mice did not cause any significant inflammation, suggesting that PNIPAAm and its copolymers present excellent biocompatibility and could be used in regenerative medicine [33]. In another study by Ekerdt et al., PNIPAAm was combined with HA and formed a 3D biomaterial that enabled the encapsulation of human pluripotent stem cells at low temperatures. Encapsulated cells survived and proliferated for a prolonged period of time and maintained their pluripotency, as they stained positive for known embryonic pluripotent markers, Nanog and Oct4, and were able to differentiate into the three germ layers, mesoderm, endoderm and ectoderm [125]. In a recent study, Vickers et al. utilized a PNIPAAm-co-DMAc ( $\mathrm{N}^{\prime}$-dimethylacrylamide) hydrogel crosslinked with laponite, the L-PNIPAAm, encapsulated human MSCs and investigated whether this system could have a beneficial impact during intervertebral disc (IVD) degeneration. They found that encapsulated MSCs could survive under hypoxia and degenerate conditions and that proinflammatory factors, the key players in IVD degeneration, did not affect the phenotype or the differentiation of MSCs. Finally, they showed that this synthetic biomaterial could be an excellent candidate for the repair of nucleus pulposus during IVD degeneration, as it promoted the survival and differentiation of MSCs [46].

\subsubsection{Polyvinyl Alcohol (PVA)}

PVA is a linear synthetic polymer produced by free radical polymerization of vinyl acetate to polyvinyl acetate and subsequent hydrolysis of the acetate groups to alcohol groups [126]. PVA is not widely used in stem cell encapsulation protocols due to a number 
of reasons that make it incompatible. One of these is the PVA gelation process, which requires a number of freezing/thawing circles that greatly reduce cell viability over time, even if cryoprotectants are present [127-130]. Another reason is its low hydrophilicity, which makes its capsules adherent to tissues, obstruct cell nutrition and provoke inflammatory reactions $[127,131]$. Nonetheless, PVA has been used as a hydrogel component for the encapsulation of hMSCs. Oda et al. used PVA in combination with other polymers in order to develop 3D polymer networks for the encapsulation of hMSCs. They observed that cell proliferation was extremely sensitive to the mechanical properties of the hydrogel and appropriate modifications were required in order to overcome this obstacle [132].

\section{The Role of Hydrogels in Stem Cell Encapsulation}

Cell encapsulation provides a semi-permeable barrier that allows stem cells to absorb nutrients from the environment and grow, offering their functional characteristics to tissues, while it simultaneously protects them from various aggravating factors and grants them specific biological advantages (Figure 3).

Protection from host's immune system
Enhanced immunomodulation prolongs cell persistence
Improved cell viability and proliferation
Improved cell differentiation
Continuous delivery of therapeutic agents
Protection from mechanical stress
Effective Cryopreservation

Figure 3. Benefits of stem cell encapsulation.

In this section, we discuss the benefits of stem cell encapsulation, providing examples of recent in vitro and in vivo studies.

\subsection{Protection from Host's Immune System}

The main advantage of cell encapsulation, regarding the protection against host immune responses, is the "camouflage" of stem cells against host antibodies, which is achieved by enclosing the stem cells into the semipermeable membrane, thus limiting the access of antibodies to cell surface markers that could be potentially recognized as threats by the immune system [55]. Zhang et al. showed that the encapsulation of embryonic stem cells with alginate-chitosan-alginate resulted in reduced production of IgG antibodies from the host when the encapsulated cells were transplanted into the animal [133]. In a recent study, Mao et al. encapsulated MSCs in alginate-based hydrogels, intravenously injected them into mice and observed increased MSC survival and overall immunomodulatory capacity. In addition, using an allogenic model of bone marrow (BM) transplantation, they showed that encapsulated MSCs were substantially protected against the host's immune responses, while they also were able to produce immunomodulatory cytokines after treatment with inflammatory mediators [134]. The significant benefit of cell encapsulation for the protection from the host's immune responses was also shown in a study by Tang et al. When human cardiac stem cells were encapsulated in PNIPAAm and then transferred into mouse and pig models of myocardial infarction, they did not only cause any immunoreaction, but they also promoted heart healing, compared with non-encapsulated cells, which provoked the host's immune responses and failed to repair the myocardium [37]. On the other hand, there is also a study on MSC transplantation, in which their encapsulation with alginate alone resulted in increased antibody production [135], suggesting that the encapsulating biomaterial plays a crucial role in immunogenicity.

\subsection{Enhanced Immunomodulation Prolongs Cell Persistence}

Stem cell encapsulation provides another significant benefit and that is the increased persistence of the encased stem cells due to their enhanced immunomodulation poten- 
tial. Swartzlander et al. and Saldana et al. showed that MSCs encapsulated in hydrogels produced high amounts of Prostaglandin E2 (PGE2), which then attenuated the pro-inflammatory properties of macrophages $[136,137]$. In the first study, encapsulated and undifferentiated MSCs showed reduced host immune responses when transplanted to mice, in comparison to either empty transplanted hydrogels or hydrogels containing differentiating MSCs. This suggests that MSCs at early stages of differentiation can regulate the host's immune responses through their interactions with local macrophages [137]. Saldana et al. then found that when MSCs were exposed to pro-inflammatory mediators prior to encapsulation, increased induction of anti-inflammatory responses in macrophages was observed, suggesting that the pro-inflammatory pretreatment together with the encapsulation could result in effective immunomodulation and, ultimately, increased cell persistence [136]. In accordance with these findings is the study by Mao et al., in which MSCs encapsulated in alginate and subsequently injected into animals showed high persistence, even in the presence of the host's immune responses. Again, when encapsulated MSCs were first pretreated with pro-inflammatory cytokines, they presented with high expression levels of immunomodulatory-associated cytokines, leading to a successful transplantation of allogeneic donor cells into the host's blood and bone marrow [134]. In another study by Leijs et al., it was shown that encapsulated MSCs produced immunomodulatory mediators, which in turn inhibited $\mathrm{T}$ cell proliferation for up to 30 days of in vitro culture. In addition, they observed that encapsulated MSCs were detectable in animals for up to 5 weeks after transplantation, while non-encapsulated MSCs failed to survive after one week [138]. In a more recent study using PEG as the encapsulating biomaterial, Young et al. encapsulated allogeneic rat ADSCs, administrated them through intramuscular injection in other rats and, in contrast to animals that received ADSCs in saline, they observed high cell densities at weeks 1,2 and 4. Furthermore, they examined the host's innate immunity profile and found that although there was an infiltration of M1 macrophages into the transplanted hydrogels, there were also M2 macrophages surrounding them. Finally, they observed signs of angiogenesis in the area surrounding the transplanted hydrogels, suggesting that the system of PEG-encased ADSCs could shift the host's inflammatory responses, promoting angiogenesis and enhancing cell persistence [17].

The benefit of encapsulation in prolonging stem cell survival and, therefore, cell persistence is also highlighted by Park et al., who combined HA with mussel adhesive protein (MAP), a protein found in mussels that enables them to attach themselves on surfaces, to encapsulate ADSCs. They showed that under hypoxia conditions, this complex biomaterial enabled ADSCs to adjust and express the hypoxia-inducible factor $1 \alpha$ (HIF-1 $\alpha$ ), leading to increased survival and angiogenesis when examined in vivo [18]. In another study from the same laboratory, it was shown that encapsulated MSCs in HA/MAP coacervate had a high survival rate when transplanted into the damaged myocardium, induced angiogenesis and promoted myocardium healing, suggesting that MAP is an essential addition to encapsulation that prolongs cell survival [40].

Finally, García et al. boosted the immunomodulatory capacity of encapsulated MSCs by tethering PEG hydrogel with interferon gamma (IFN- $\gamma$ ) and observed that MSCs produced increased concentrations of interleukin (IL)-6, CXCL10, CCL2, CCL8 and macrophage colony-stimulating factor (M-CSF) and inhibited T-cell proliferation and monocyte-derived dendritic cell differentiation. In addition, when IFN- $\gamma$-PEG-encapsulated MSCs were transplanted into immunocompromised or immunocompetent mice with biopsy-injured colons, they found enhanced mucosal healing, suggesting that this complex system could play an important role in therapeutic strategies of mucosal wound healing in inflammatory bowel diseases (IBDs) [53].

\subsection{Improved Cell Viability and Proliferation}

During encapsulation, several biomaterials can maintain or even improve stem cell viability and proliferation and prolong culturing survival. This great benefit of the encapsulation process is due to the secured environment that is offered, an enclosed niche 
simulating the native physiological conditions required for cell survival and proliferation. As already mentioned, hyaluronan-based hydrogel can promote transplanted retinal stem cell survival through interactions between the hydrogel and the stem cells [41]. In another study, Hidalgo San Jose et al. showed that neural stem cells and dental pulp stem cells encapsulated in alginate-collagen hydrogel maintain their viability and neuronal differentiation capacity for a prolonged period of time, even when transferred into an ex vivo spinal cord slice model, while non-encapsulated stem cells were undetectable ten days after transplantation. In addition, encapsulated neural stem cells exhibited high proliferation rates in in vitro experiments, as well as minor proliferation in the ex vivo model, whereas dental pulp stem cells did not show any signs of proliferation [47].

The benefits of stem cell encapsulation for cell viability and survival are also highlighted in the study by Dong et al. Using an animal model for burn wound healing, Dong et al. showed that hyaluronic-acid-encapsulated ASCs survived for longer at the site of the burn wound compared to non-encapsulated cells, eventually leading to better and more rapid healing [139]. In the same manner, Deng et al. investigated whether the combination of Pluronic F-127 with sodium ascorbyl phosphate as encapsulating biomaterials could affect the survival and healing properties of Wharton's jelly MSCs (WJMSCs) in an animal model of skin wound healing. Indeed, mice that received encapsulated WJMSCs inside Pluronic F-127 and sodium ascorbyl phosphate showed increased healing rates when compared to either non-encapsulated WJMSCs, Pluronic F-127-alone or sodium ascorbyl phosphate-alone encapsulated WJMSCs, as their dermis thickened, the number of hair follicles increased and the scarring decreased [50]. In another study, using alginate as the encapsulating biomaterial, Khatab et al. showed that after the intra-articular injection of MSCs into the knee joints of rats, the survival rates of encapsulated MSCs were significantly higher compared to non-encapsulated cells. Nonetheless, using a rat model of osteoarthritis, Khatab et al. did not observe any significant difference between encapsulated and non-encapsulated MSCs in regard to their therapeutic effect, as the pain, the cartilage damage and the synovial inflammation remained unchanged between the studied groups [140]. In an another recent study, Chen et al. utilized a mouse model of myocardial infarction and showed that transglutaminase cross-linked gelatin-encapsulated ADSCs were more successfully engrafted at the injury site, in comparison to non-encapsulated ADSCs, leading to improved cardioprotection [141].

Finally, Ho et al. examined the combination of bone morphogenetic protein-2 (BMP-2) with alginate-based hydrogels on MSCs. By synthesizing BMP-2-containing alginate-based hydrogels, they observed that the encapsulated MSCs remained alive in vitro, differentiated towards the osteogenic lineages, and no significant apoptosis was observed in the presence or not of BMP-2 [142], overcoming the obstacle that high concentrations of BMP-2 induce apoptosis to non-encapsulated stem cells [143]. When encapsulated MSCs were transplanted into rats with femoral segmental defects, Ho et al. observed high cell viability and increased bone volumes after 12 weeks, suggesting that this could be an efficient approach for osteogenic therapeutic strategy [142].

\subsection{Improved Cell Differentiation}

Cell encapsulation provides a semi-permeable membrane that surrounds the stem cells, creating an ideal niche both for maintaining their growth and for enhancing their differentiation process. Depending on the properties of the encapsulating biomaterial, the type and density of enclosed stem cells and the possible addition of exogenous factors, stem cells can differentiate towards various lineages. For example, de Vries-van Melle et al. compared alginate, fibrin and HA-PNIPAAm hydrogels on the chondrogenesis differentiation of encapsulated hBMSCs in an osteochondral environment and concluded that it is hydrogel-dependent, after culture in an in vitro and in vivo osteochondral biopsy model [144]. As far as the properties of the encapsulating biomaterial are concerned, Žigon-Branc et al. showed that the differentiation towards the osteogenic or the chondrogenic pathway of ADSCs, encapsulated in gelatin-based hydrogels, clearly depends on the 
biomaterial stiffness [29]. As for the density of the encapsulated stem cells, Chang et al. observed that higher mesenchymal stem cell densities encapsulated in a PEG-fibrinogen hydrogel resulted in significantly greater growth and differentiation rates towards the cardiac lineage [38]. As for the addition of exogenous stimulating factors, $\mathrm{Li}$ et al. used a PEG-based hydrogel attached with a neurogenic differentiation factor, IFN- $\gamma$, for the encapsulation of neural stem cells and observed that almost $60 \%$ of them had been differentiated towards neuron cells, without the need for additional growth factors in the culture media, suggesting that this complex biomaterial could be a useful tool for neural regeneration applications where tissue access is difficult [145]. Finally, in a recent study by Hung et al., taking into account a combination of parameters-alginate stiffness, arginylglycylaspartic acid (RGD) content and spheroid cellularity - a tunable model for the maintenance and differentiation of specific cell types was established, while underlining the significance of the interplay among the aforementioned parameters on phenotype retention [146].

\subsection{Continuous Delivery of Therapeutic Agents}

Cell encapsulation offers a great advantage in therapeutic strategies, as encapsulated cells can continuously secrete various factors for a prolonged period, achieving in this way high concentrations of secreted molecules and, ultimately, the desired and effective therapeutic levels. Additionally, stem cells can be first genetically modified to express any possible protein and then encapsulated and transplanted, as a drug delivery system, to the tissue of interest in order to offer their therapeutic properties [147]. Regarding the latter, Lin et al. genetically modified bone marrow stem cells to overexpress BMP-2 and then encapsulated them in hydrogel scaffolds, which were transplanted into immunodeficient mice in order to study their role in bone formation. Indeed, encapsulated and genetically modified stem cells continuously expressed high quantities of BMP-2, differentiated towards the osteogenic lineage, without the need of any exogenous addition of BMP-2, and when transplanted in mice, they successfully induced bone formation [20]. In another study of a hearing loss animal model, Scheper et al. observed that cochlear implants coated with encapsulated and genetically engineered MSCs that overexpressed the brain-derived neurotrophic factor (BDNF) could prevent spiral ganglion neurons from degradation and, thus, significantly restore hearing loss [42]. In a recent study on myocardial infraction, Park et al. encapsulated MSCs in a new platform called "adhesive protein-based immiscible condensed liquid system" (APICLS), which consists of MAP and anionic HA, administrated them through intramyocardial injection into the myocardium and ultimately observed improved cardiac function, with enhanced angiogenesis, reduced scar formation and recovered contractive force [40]. Finally, Mandal et al. investigated whether encapsulated WJMSCs could have therapeutic potential in breast cancer. Encapsulated WJMSCs in alginate-based hydrogel overexpressed anti-inflammatory cytokines and the tumor invasion suppressor protein E-cadherin, and when administered to cancer stem cells (CSCs), they demonstrated anti-tumorigenic activity, as they diminished CSC s' viability, inhibited their migration and blocked angiogenesis [23].

\subsection{Protection from Mechanical Stress}

Another benefit of cell encapsulation is the protection of stem cells from mechanical forces encountered during in vitro and in vivo experiments, mainly caused by fluid and solid stresses. The polymer concentration, its molecular weight and its cross-linking density are all key elements that define the mechanical properties of encapsulating materials and play an important role in the protection of stem cells from mechanical stresses [55]. Such great stresses can be observed during stem cell syringe transplantation and Aguado et al. showed that the viability of different kind of stem cells could be greatly improved by encapsulating them in hydrogel carriers [148]. In a more recent study, Foster et al. developed a special type of hydrogel that could significantly protect induced pluripotent stem cell-derived endothelial cells during syringe injections in an animal model for the treatment of peripheral arterial disease [149]. 


\subsection{Effective Cryopreservation}

Encapsulation provides another beneficial feature and that is effective stem cell cryopreservation during the freezing-thawing process. Khetan et al. encapsulated MSCs in HA- and polyethylene glycol-based hydrogels, froze them in the presence of dimethyl sulfoxide (DMSO) and found that around $40-60 \%$ of cells were still alive after thawing and competent enough to differentiate into adipogenic cells [150]. In another study, Zhao et al. utilized alginate-based hydrogel for the encapsulation of porcine ADSCs in core-shell microcapsules in order to investigate the cryopreservative properties of this system during the cell-freezing process. They found that this system acts as an effective cryopreservation method, as it not only greatly improves the stem cell viability (56-73\%) compared with non-encapsulated cells (21-25\%) but also requires minimal quantities of cryoprotective agents (CPAs) [151]. In a similar manner, Huang et al. investigated whether the encapsulation of stem cells in alginate-based hydrogels could protect them from dying, due to the intracellular ice formation during the process of thawing, without the need for high-concentration CPAs. Indeed, they observed that both embryonic and adipose-derived encapsulated stem cells retained high viability percentages after freeze-thaw cycles, in contrast to non-encapsulated cells. In addition, they reported that alginate encapsulation allows for higher cell sample volumes to be effectively cryopreserved, with up to a four-times lower concentration of CPAs, suggesting that it could be a preferable choice for cryopreservation when stem cells are intended for clinical applications in regenerative medicine [152]. Sambu et al. showed that the encapsulation of mouse embryonic stem cells in arginine-glycine-aspartic acid-serine-coupled calcium alginates, a system that further enables the attachment of stem cells with the hydrogel, had indeed a beneficial effect in viability after thawing, achieving a viability of $93 \pm 2 \%$, when compared with either unmodified hydrogels or uncapsulated cells (62 $\pm 3 \%$ and $52 \pm 2 \%$, respectively) [153]. Finally, Pravdyuk et al. examined the effectiveness of three different freezing protocols in the viability and differentiation capacity of alginate encapsulated or non-encapsulated MSCs. They showed that among the three studied freezing protocols, only one of them achieved the highest viability percentage, metabolism activity and differentiation capacity, but they found no differences in encapsulated or non-encapsulated MSCs, suggesting that encapsulation is an equally effective technique for cell cryopreservation [154].

\section{Discussion-Future Perspectives}

Cell encapsulation is a process during which stem cells are surrounded by a semipermeable membrane, providing protection against the host immune responses while, at the same time, permitting the diffusion of required nutrients and secretion molecules. Encapsulation technology might solve a wide range of challenges in the field of cell-based therapies and regenerative medicine, especially when the therapeutic substance is a cellsecretory molecule. Different cell types need to be used each time, with different properties and functionality, in different tissues and in a heterogeneous group of diseases. Therefore, the encapsulation, in each case, must have different characteristics in order to respond positively to the therapeutic intervention.

To date, the development and use of a wide range of natural and synthetic materials has provided a number of advantages in stem cell encapsulation and its use in regenerative medicine, from experimental models to cell-based therapies. Taking into consideration the aforementioned advantages of cell encapsulation, many researchers have applied this technology, utilizing cells of different types, as a possible therapeutic treatment in various preclinical and clinical trials $[155,156]$. Regarding encapsulated stem cells, although there are numerous preclinical references to their possible beneficial role in various disease models (Table 1), there was only one Phase I/II clinical trial exploring their use as treatment in stroke patients with space-occupying intracerebral hemorrhage, which was terminated three years after its initiation, with no final results yet to be published [156-158]. However, stem cells and their use in regenerative medicine is a recent and advancing research field, with promising clinical applications to be implemented in the near future. 
In addition, although there is a wide range of well-studied hydrogels, extensive research is needed in order to precisely determine the required physiochemical properties of the chosen biomaterial, depending on the type of stem cells that will enclose, the type of organ system that will be administrated to and the specific application that will address. The various "capsule" properties, e.g., stability, permeability and biocompatibility, need to be specifically tuned for each case. Therefore, future research should be focused on biomaterials that would improve the viability of encapsulated cells, cause less unwanted immune host reactions and endure biodegradation long enough in order to provide the expected therapeutic results.

In summary, stem cell encapsulation technology is based on the combined efforts of different disciplines-material science, engineering, cell biology and medicine-each one with distinct challenges to overcome, resulting in significant, but difficult to achieve, advancements. The development of regenerative medicine and its involvement in modern therapeutic strategies, as well as the possibilities of using more types of stem cells, requires extensive study of the encapsulation capabilities and the plausible development of improved biomaterials that would fulfill these expectations.

Author Contributions: L.K. and E.F. searched the literature and wrote the manuscript. G.K. and V.P. supervised the work and revised the manuscript. All authors have read and agreed to the published version of the manuscript.

Funding: This research received no external funding.

Data Availability Statement: This is a review analysis of the literature on the subject. No new data were created in this study. Data sharing is not applicable to this article.

Conflicts of Interest: The authors declare no conflict of interest.

\section{References}

1. Fan, X.L.; Zhang, Y.; Li, X.; Fu, Q.L. Mechanisms underlying the protective effects of mesenchymal stem cell-based therapy. Cell. Mol. Life Sci. 2020. [CrossRef]

2. Paspaliaris, V.; Kolios, G. Stem cells in Osteoporosis: From Biology to New Therapeutic Approaches. Stem Cells Int. 2019, 2019, 1730978. [CrossRef]

3. Kolios, G.; Moodley, Y. Introduction to stem cells and regenerative medicine. Respiration 2013, 85, 3-10. [CrossRef]

4. Sumer, H.; Liu, J.; Roh, S. Mesenchymal Stem Cells and Regenerative Medicine. Stem Cells Int. 2018, 2018, 9810972. [CrossRef]

5. Tao, Y.C.; Wang, M.L.; Chen, E.Q.; Tang, H. Stem Cells Transplantation in the Treatment of Patients with Liver Failure. Curr. Stem Cell Res. Ther. 2018, 13, 193-201. [CrossRef]

6. Lee, J.H.; Park, H.J.; Kim, Y.A.; Lee, D.H.; Noh, J.K.; Kwon, C.H.; Jung, S.M.; Lee, S.K. Differentiation and major histocompatibility complex antigen expression in human liver-derived stem cells. Transplant. Proc. 2012, 44, 1113-1115. [CrossRef]

7. Wang, Y.; Tian, M.; Wang, F.; Heng, B.C.; Zhou, J.; Cai, Z.; Liu, H. Understanding the Immunological Mechanisms of Mesenchymal Stem Cells in Allogeneic Transplantation: From the Aspect of Major Histocompatibility Complex Class I. Stem Cells Dev. 2019, 28, 1141-1150. [CrossRef]

8. Galvez-Martin, P.; Martin, J.M.; Ruiz, A.M.; Clares, B. Encapsulation in Cell Therapy: Methodologies, Materials, and Clinical Applications. Curr. Pharm. Biotechnol. 2017, 18, 365-377. [CrossRef]

9. Kühtreiber, W.M.; Lanza, R.P.; Chick, W.L. Cell Encapsulation Technology and Therapeutics; Springer Science \& Business Media: New York, NY, USA, 1999.

10. Aeron, G.; Shiwangi, M. Immobilization and microencapsulation. J. Adv. Res. Biotechnol. 2017, 2, 1-4. [CrossRef]

11. Hashemi, M.; Kalalinia, F. Application of encapsulation technology in stem cell therapy. Life Sci. 2015, 143, 139-146. [CrossRef]

12. Chang, T.M. Semipermeable microcapsules. Science 1964, 146, 524-525. [CrossRef]

13. Kanda, P.; Alarcon, E.I.; Yeuchyk, T.; Parent, S.; De Kemp, R.A.; Variola, F.; Courtman, D.; Stewart, D.J.; Davis, D.R. Deterministic Encapsulation of Human Cardiac Stem Cells in Variable Composition Nanoporous Gel Cocoons To Enhance Therapeutic Repair of Injured Myocardium. ACS Nano 2018, 12, 4338-4350. [CrossRef]

14. Santos-Vizcaino, E.; Orive, G.; Pedraz, J.L.; Hernandez, R.M. Clinical Applications of Cell Encapsulation Technology. Methods Mol. Biol. 2020, 2100, 473-491. [CrossRef]

15. Cerqueira, M.T.; Da Silva, L.P.; Santos, T.C.; Pirraco, R.P.; Correlo, V.M.; Reis, R.L.; Marques, A.P. Gellan gum-hyaluronic acid spongy-like hydrogels and cells from adipose tissue synergize promoting neoskin vascularization. ACS Appl. Mater. Interfaces 2014, 6, 19668-19679. [CrossRef] 
16. Steiner, D.; Lingens, L.; Fischer, L.; Kohn, K.; Detsch, R.; Boccaccini, A.R.; Fey, T.; Greil, P.; Weis, C.; Beier, J.P.; et al. Encapsulation of Mesenchymal Stem Cells Improves Vascularization of Alginate-Based Scaffolds. Tissue Eng. Part A 2018, 24, $1320-1331$. [CrossRef]

17. Young, S.A.; Flynn, L.E.; Amsden, B.G. Adipose-Derived Stem Cells in a Resilient In Situ Forming Hydrogel Modulate Macrophage Phenotype. Tissue Eng. Part A 2018, 24, 1784-1797. [CrossRef]

18. Park, T.Y.; Jeon, E.Y.; Kim, H.J.; Choi, B.H.; Cha, H.J. Prolonged cell persistence with enhanced multipotency and rapid angiogenesis of hypoxia pre-conditioned stem cells encapsulated in marine-inspired adhesive and immiscible liquid microdroplets. Acta Biomater. 2019, 86, 257-268. [CrossRef]

19. Leslie, S.K.; Cohen, D.J.; Boyan, B.D.; Schwartz, Z. Production of osteogenic and angiogenic factors by microencapsulated adipose stem cells varies with culture conditions. J. Biomed. Mater. Res. B Appl. Biomater. 2020, 108, 1857-1867. [CrossRef] [PubMed]

20. Lin, H.; Tang, Y.; Lozito, T.P.; Oyster, N.; Wang, B.; Tuan, R.S. Efficient in vivo bone formation by BMP-2 engineered human mesenchymal stem cells encapsulated in a projection stereolithographically fabricated hydrogel scaffold. Stem Cell. Res. Ther. 2019, 10, 254. [CrossRef] [PubMed]

21. Pentlavalli, S.; Chambers, P.; Sathy, B.N.; O’Doherty, M.; Chalanqui, M.; Kelly, D.J.; Haut-Donahue, T.; McCarthy, H.O.; Dunne, N.J. Simple Radical Polymerization of Poly(Alginate-Graft-N-Isopropylacrylamide) Injectable Thermoresponsive Hydrogel with the Potential for Localized and Sustained Delivery of Stem Cells and Bioactive Molecules. Macromol. Biosci. 2017, 17. [CrossRef]

22. Heo, D.N.; Hospodiuk, M.; Ozbolat, I.T. Synergistic interplay between human MSCs and HUVECs in 3D spheroids laden in collagen/fibrin hydrogels for bone tissue engineering. Acta Biomater. 2019, 95, 348-356. [CrossRef] [PubMed]

23. Mandal, S.; Arfuso, F.; Sethi, G.; Dharmarajan, A.; Warrier, S. Encapsulated human mesenchymal stem cells (eMSCs) as a novel anti-cancer agent targeting breast cancer stem cells: Development of 3D primed therapeutic MSCs. Int. J. Biochem. Cell Biol. 2019, 110, 59-69. [CrossRef] [PubMed]

24. Rogan, H.; Ilagan, F.; Yang, F. Comparing Single Cell Versus Pellet Encapsulation of Mesenchymal Stem Cells in Three-Dimensional Hydrogels for Cartilage Regeneration. Tissue Eng. Part A 2019, 25, 1404-1412. [CrossRef]

25. Naderi-Meshkin, H.; Andreas, K.; Matin, M.M.; Sittinger, M.; Bidkhori, H.R.; Ahmadiankia, N.; Bahrami, A.R.; Ringe, J. Chitosanbased injectable hydrogel as a promising in situ forming scaffold for cartilage tissue engineering. Cell Biol. Int. 2014, 38, 72-84. [CrossRef] [PubMed]

26. Brunelle, A.R.; Horner, C.B.; Low, K.; Ico, G.; Nam, J. Electrospun thermosensitive hydrogel scaffold for enhanced chondrogenesis of human mesenchymal stem cells. Acta Biomater. 2018, 66, 166-176. [CrossRef] [PubMed]

27. Liu, Y.; Shu, X.Z.; Prestwich, G.D. Osteochondral defect repair with autologous bone marrow-derived mesenchymal stem cells in an injectable, in situ, cross-linked synthetic extracellular matrix. Tissue Eng. 2006, 12, 3405-3416. [CrossRef]

28. Diniz, I.M.; Chen, C.; Xu, X.; Ansari, S.; Zadeh, H.H.; Marques, M.M.; Shi, S.; Moshaverinia, A. Pluronic F-127 hydrogel as a promising scaffold for encapsulation of dental-derived mesenchymal stem cells. J. Mater. Sci. Mater. Med. 2015, 26, 153. [CrossRef]

29. Zigon-Branc, S.; Markovic, M.; Van Hoorick, J.; Van Vlierberghe, S.; Dubruel, P.; Zerobin, E.; Baudis, S.; Ovsianikov, A. Impact of Hydrogel Stiffness on Differentiation of Human Adipose-Derived Stem Cell Microspheroids. Tissue Eng. Part A 2019, 25, 1369-1380. [CrossRef]

30. Dollinger, B.R.; Gupta, M.K.; Martin, J.R.; Duvall, C.L. Reactive Oxygen Species Shielding Hydrogel for the Delivery of Adherent and Nonadherent Therapeutic Cell Types. Tissue Eng. Part A 2017, 23, 1120-1131. [CrossRef]

31. Fath-Bayati, L.; Ai, J. Assessment of mesenchymal stem cell effect on foreign body response induced by intraperitoneally implanted alginate spheres. J. Biomed. Mater. Res. A 2020, 108, 94-102. [CrossRef]

32. McCrary, M.R.; Jesson, K.; Wei, Z.Z.; Logun, M.; Lenear, C.; Tan, S.; Gu, X.; Jiang, M.Q.; Karumbaiah, L.; Yu, S.P.; et al. Cortical Transplantation of Brain-Mimetic Glycosaminoglycan Scaffolds and Neural Progenitor Cells Promotes Vascular Regeneration and Functional Recovery after Ischemic Stroke in Mice. Adv. Healthc. Mater. 2020, 9, e1900285. [CrossRef] [PubMed]

33. Niu, H.; Li, C.; Guan, Y.; Dang, Y.; Li, X.; Fan, Z.; Shen, J.; Ma, L.; Guan, J. High oxygen preservation hydrogels to augment cell survival under hypoxic condition. Acta Biomater. 2020, 105, 56-67. [CrossRef] [PubMed]

34. Lalegul-Ulker, O.; Seker, S.; Elcin, A.E.; Elcin, Y.M. Encapsulation of bone marrow-MSCs in PRP-derived fibrin microbeads and preliminary evaluation in a volumetric muscle loss injury rat model: Modular muscle tissue engineering. Artif. Cells Nanomed. Biotechnol. 2019, 47, 10-21. [CrossRef] [PubMed]

35. Li, Z.; Fan, Z.; Xu, Y.; Niu, H.; Xie, X.; Liu, Z.; Guan, J. Thermosensitive and Highly Flexible Hydrogels Capable of Stimulating Cardiac Differentiation of Cardiosphere-Derived Cells under Static and Dynamic Mechanical Training Conditions. ACS Appl. Mater. Interfaces 2016, 8, 15948-15957. [CrossRef]

36. Li, Z.; Fan, Z.; Xu, Y.; Lo, W.; Wang, X.; Niu, H.; Li, X.; Xie, X.; Khan, M.; Guan, J. pH-Sensitive and Thermosensitive Hydrogels as Stem-Cell Carriers for Cardiac Therapy. ACS Appl. Mater. Interfaces 2016, 8, 10752-10760. [CrossRef]

37. Tang, J.; Cui, X.; Caranasos, T.G.; Hensley, M.T.; Vandergriff, A.C.; Hartanto, Y.; Shen, D.; Zhang, H.; Zhang, J.; Cheng, K. Heart Repair Using Nanogel-Encapsulated Human Cardiac Stem Cells in Mice and Pigs with Myocardial Infarction. ACS Nano 2017, 11, 9738-9749. [CrossRef]

38. Chang, S.; Finklea, F.; Williams, B.; Hammons, H.; Hodge, A.; Scott, S.; Lipke, E. Emulsion-based encapsulation of pluripotent stem cells in hydrogel microspheres for cardiac differentiation. Biotechnol. Prog. 2020, e2986. [CrossRef]

39. Li, X.; Zhou, J.; Liu, Z.; Chen, J.; Lu, S.; Sun, H.; Li, J.; Lin, Q.; Yang, B.; Duan, C.; et al. A PNIPAAm-based thermosensitive hydrogel containing SWCNTs for stem cell transplantation in myocardial repair. Biomaterials 2014, 35, 5679-5688. [CrossRef] 
40. Park, T.Y.; Oh, J.M.; Cho, J.S.; Sim, S.B.; Lee, J.; Cha, H.J. Stem cell-loaded adhesive immiscible liquid for regeneration of myocardial infarction. J. Control. Release 2020, 321, 602-615. [CrossRef]

41. Ballios, B.G.; Cooke, M.J.; Donaldson, L.; Coles, B.L.; Morshead, C.M.; van der Kooy, D.; Shoichet, M.S. A Hyaluronan-Based Injectable Hydrogel Improves the Survival and Integration of Stem Cell Progeny following Transplantation. Stem Cell Rep. 2015, 4, 1031-1045. [CrossRef]

42. Scheper, V.; Hoffmann, A.; Gepp, M.M.; Schulz, A.; Hamm, A.; Pannier, C.; Hubka, P.; Lenarz, T.; Schwieger, J. Stem Cell Based Drug Delivery for Protection of Auditory Neurons in a Guinea Pig Model of Cochlear Implantation. Front. Cell. Neurosci. 2019, 13, 177. [CrossRef] [PubMed]

43. Gomes, E.D.; Mendes, S.S.; Leite-Almeida, H.; Gimble, J.M.; Tam, R.Y.; Shoichet, M.S.; Sousa, N.; Silva, N.A.; Salgado, A.J. Combination of a peptide-modified gellan gum hydrogel with cell therapy in a lumbar spinal cord injury animal model. Biomaterials 2016, 105, 38-51. [CrossRef] [PubMed]

44. Zarei-Kheirabadi, M.; Sadrosadat, H.; Mohammadshirazi, A.; Jaberi, R.; Sorouri, F.; Khayyatan, F.; Kiani, S. Human embryonic stem cell-derived neural stem cells encapsulated in hyaluronic acid promotes regeneration in a contusion spinal cord injured rat. Int. J. Biol. Macromol. 2020, 148, 1118-1129. [CrossRef]

45. Kumar, D.; Gerges, I.; Tamplenizza, M.; Lenardi, C.; Forsyth, N.R.; Liu, Y. Three-dimensional hypoxic culture of human mesenchymal stem cells encapsulated in a photocurable, biodegradable polymer hydrogel: A potential injectable cellular product for nucleus pulposus regeneration. Acta Biomater. 2014, 10, 3463-3474. [CrossRef] [PubMed]

46. Vickers, L.; Thorpe, A.A.; Snuggs, J.; Sammon, C.; Le Maitre, C.L. Mesenchymal stem cell therapies for intervertebral disc degeneration: Consideration of the degenerate niche. JOR Spine 2019, 2, e1055. [CrossRef] [PubMed]

47. Hidalgo San Jose, L.; Stephens, P.; Song, B.; Barrow, D. Microfluidic Encapsulation Supports Stem Cell Viability, Proliferation, and Neuronal Differentiation. Tissue Eng. Part C Methods 2018, 24, 158-170. [CrossRef] [PubMed]

48. Liu, C.; Fan, L.; Xing, J.; Wang, Q.; Lin, C.; Liu, C.; Deng, X.; Ning, C.; Zhou, L.; Rong, L.; et al. Inhibition of astrocytic differentiation of transplanted neural stem cells by chondroitin sulfate methacrylate hydrogels for the repair of injured spinal cord. Biomater. Sci. 2019, 7, 1995-2008. [CrossRef] [PubMed]

49. Aijaz, A.; Teryek, M.; Goedken, M.; Polunas, M.; Olabisi, R.M. Coencapsulation of ISCs and MSCs Enhances Viability and Function of both Cell Types for Improved Wound Healing. Cell. Mol. Bioeng. 2019, 12, 481-493. [CrossRef]

50. Deng, Q.; Huang, S.; Wen, J.; Jiao, Y.; Su, X.; Shi, G.; Huang, J. PF-127 hydrogel plus sodium ascorbyl phosphate improves Wharton's jelly mesenchymal stem cell-mediated skin wound healing in mice. Stem Cell Res. Ther. 2020, 11, 143. [CrossRef]

51. Kaisang, L.; Siyu, W.; Lijun, F.; Daoyan, P.; Xian, C.J.; Jie, S. Adipose-derived stem cells seeded in Pluronic F-127 hydrogel promotes diabetic wound healing. J. Surg. Res. 2017, 217, 63-74. [CrossRef]

52. Al-Jaibaji, O.; Swioklo, S.; Gijbels, K.; Vaes, B.; Figueiredo, F.C.; Connon, C.J. Alginate encapsulated multipotent adult progenitor cells promote corneal stromal cell activation via release of soluble factors. PLoS ONE 2018, 13, e0202118. [CrossRef] [PubMed]

53. Garcia, J.R.; Quiros, M.; Han, W.M.; O’Leary, M.N.; Cox, G.N.; Nusrat, A.; Garcia, A.J. IFN-gamma-tethered hydrogels enhance mesenchymal stem cell-based immunomodulation and promote tissue repair. Biomaterials 2019, 220, 119403. [CrossRef] [PubMed]

54. Bajaj, P.; Schweller, R.M.; Khademhosseini, A.; West, J.L.; Bashir, R. 3D biofabrication strategies for tissue engineering and regenerative medicine. Annu. Rev. Biomed. Eng. 2014, 16, 247-276. [CrossRef] [PubMed]

55. Hasturk, O.; Kaplan, D.L. Cell armor for protection against environmental stress: Advances, challenges and applications in microand nanoencapsulation of mammalian cells. Acta Biomater. 2019, 95, 3-31. [CrossRef] [PubMed]

56. Kim, H.; Bae, C.; Kook, Y.M.; Koh, W.G.; Lee, K.; Park, M.H. Mesenchymal stem cell 3D encapsulation technologies for biomimetic microenvironment in tissue regeneration. Stem Cell Res. Ther. 2019, 10, 51. [CrossRef]

57. Nezhad-Mokhtari, P.; Ghorbani, M.; Roshangar, L.; Soleimani Rad, J. Chemical gelling of hydrogels-based biological macromolecules for tissue engineering: Photo- and enzymatic-crosslinking methods. Int. J. Biol. Macromol. 2019, 139, 760-772. [CrossRef]

58. Kamperman, T.; Karperien, M.; Le Gac, S.; Leijten, J. Single-Cell Microgels: Technology, Challenges, and Applications. Trends Biotechnol. 2018, 36, 850-865. [CrossRef]

59. Peppas, N.A.; Khare, A.R. Preparation, structure and diffusional behavior of hydrogels in controlled release. Adv. Drug Del. Rev. 1993, 11, 1-35. [CrossRef]

60. Wichterle, O.; Lím, D. Hydrophilic Gels for Biological Use. Nature 1960, 185, 117-118. [CrossRef]

61. Lee, D.; Cho, S.; Park, H.S.; Kwon, I. Ocular Drug Delivery through pHEMA-Hydrogel Contact Lenses Co-Loaded with Lipophilic Vitamins. Sci. Rep. 2016, 6, 34194. [CrossRef]

62. Caló, E.; Khutoryanskiy, V.V. Biomedical applications of hydrogels: A review of patents and commercial products. Eur. Polym. J. 2015, 65, 252-267. [CrossRef]

63. Peppas, N.A.; Bures, P.; Leobandung, W.; Ichikawa, H. Hydrogels in pharmaceutical formulations. Eur. J. Pharm. Biopharm. 2000, 50, 27-46. [CrossRef]

64. Drury, J.L.; Mooney, D.J. Hydrogels for tissue engineering: Scaffold design variables and applications. Biomaterials 2003, 24, 4337-4351. [CrossRef]

65. Uludag, H.; De Vos, P.; Tresco, P.A. Technology of mammalian cell encapsulation. Adv. Drug Deliv. Rev. 2000, 42, 29-64. [CrossRef]

66. Ahmed, E.M. Hydrogel: Preparation, characterization, and applications: A review. J. Adv. Res. 2015, 6, 105-121. [CrossRef] 
67. Zucca, P.; Fernandez-Lafuente, R.; Sanjust, E. Agarose and Its Derivatives as Supports for Enzyme Immobilization. Molecules 2016, 21, 1577. [CrossRef]

68. Dang, S.M.; Gerecht-Nir, S.; Chen, J.; Itskovitz-Eldor, J.; Zandstra, P.W. Controlled, scalable embryonic stem cell differentiation culture. Stem Cells 2004, 22, 275-282. [CrossRef] [PubMed]

69. Batorsky, A.; Liao, J.; Lund, A.W.; Plopper, G.E.; Stegemann, J.P. Encapsulation of adult human mesenchymal stem cells within collagen-agarose microenvironments. Biotechnol. Bioeng. 2005, 92, 492-500. [CrossRef] [PubMed]

70. Sakai, S.; Hashimoto, I.; Kawakami, K. Production of cell-enclosing hollow-core agarose microcapsules via jetting in waterimmiscible liquid paraffin and formation of embryoid body-like spherical tissues from mouse ES cells enclosed within these microcapsules. Biotechnol. Bioeng. 2008, 99, 235-243. [CrossRef] [PubMed]

71. Benavente-Babace, A.; Haase, K.; Stewart, D.J.; Godin, M. Strategies for controlling egress of therapeutic cells from hydrogel microcapsules. J. Tissue Eng. Regen. Med. 2019, 13, 612-624. [CrossRef]

72. Sarker, B.; Zehnder, T.; Rath, S.N.; Horch, R.E.; Kneser, U.; Detsch, R.; Boccaccini, A.R. Oxidized Alginate-Gelatin Hydrogel: A Favorable Matrix for Growth and Osteogenic Differentiation of Adipose-Derived Stem Cells in 3D. ACS Biomater. Sci. Eng. 2017, 3, 1730-1737. [CrossRef]

73. Rezaei, S.; Shakibaie, M.; Kabir-Salmani, M.; Soltani Moghaddam, M.; Rezvani, M.; Shahali, M.; Naseri, M. Improving the Growth Rate of Human Adipose-Derived Mesenchymal Stem Cells in Alginate/Gelatin Versus Alginate Hydrogels. Iran. J. Biotechnol. 2016, 14, 1-8. [CrossRef] [PubMed]

74. Popa, E.; Reis, R.; Gomes, M. Chondrogenic phenotype of different cells encapsulated in kappa-carrageenan hydrogels for cartilage regeneration strategies. Biotechnol. Appl. Biochem. 2012, 59, 132-141. [CrossRef] [PubMed]

75. Rocha, P.M.; Santo, V.E.; Gomes, M.E.; Reis, R.L.; Mano, J.F. Encapsulation of adipose-derived stem cells and transforming growth factor- $\beta 1$ in carrageenan-based hydrogels for cartilage tissue engineering. J. Bioact. Compat. Polym. 2011, 26, 493-507. [CrossRef]

76. Thakur, A.; Jaiswal, M.K.; Peak, C.W.; Carrow, J.K.; Gentry, J.; Dolatshahi-Pirouz, A.; Gaharwar, A.K. Injectable shear-thinning nanoengineered hydrogels for stem cell delivery. Nanoscale 2016, 8, 12362-12372. [CrossRef]

77. Kas, H.S. Chitosan: Properties, preparations and application to microparticulate systems. J. Microencapsul. 1997, $14,689-711$. [CrossRef]

78. Fedorovich, N.E.; Alblas, J.; de Wijn, J.R.; Hennink, W.E.; Verbout, A.J.; Dhert, W.J. Hydrogels as extracellular matrices for skeletal tissue engineering: State-of-the-art and novel application in organ printing. Tissue Eng. 2007, 13, 1905-1925. [CrossRef]

79. Roughley, P.; Hoemann, C.; DesRosiers, E.; Mwale, F.; Antoniou, J.; Alini, M. The potential of chitosan-based gels containing intervertebral disc cells for nucleus pulposus supplementation. Biomaterials 2006, 27, 388-396. [CrossRef]

80. Spiller, K.L.; Maher, S.A.; Lowman, A.M. Hydrogels for the repair of articular cartilage defects. Tissue Eng. Part B Rev. 2011, 17, 281-299. [CrossRef]

81. Fan, M.; Ma, Y.; Mao, J.; Zhang, Z.; Tan, H. Cytocompatible in situ forming chitosan/hyaluronan hydrogels via a metal-free click chemistry for soft tissue engineering. Acta Biomater. 2015, 20, 60-68. [CrossRef]

82. Baeurle, S.A.; Kiselev, M.G.; Makarova, E.S.; Nogovitsin, E.A. Effect of the counterion behavior on the frictional-compressive properties of chondroitin sulfate solutions. Polymer 2009, 50, 1805-1813. [CrossRef]

83. Foot, M.; Mulholland, M. Classification of chondroitin sulfate A, chondroitin sulfate C, glucosamine hydrochloride and glucosamine 6 sulfate using chemometric techniques. J. Pharm. Biomed. Anal. 2005, 38, 397-407. [CrossRef] [PubMed]

84. Karumbaiah, L.; Enam, S.F.; Brown, A.C.; Saxena, T.; Betancur, M.I.; Barker, T.H.; Bellamkonda, R.V. Chondroitin Sulfate Glycosaminoglycan Hydrogels Create Endogenous Niches for Neural Stem Cells. Bioconjug. Chem. 2015, 26, 2336-2349. [CrossRef] [PubMed]

85. Kang, K.S.; Veeder, G.T.; Mirrasoul, P.J.; Kaneko, T.; Cottrell, I.W. Agar-like polysaccharide produced by a pseudomonas species: Production and basic properties. Appl. Environ. Microbiol. 1982, 43, 1086-1091. [CrossRef] [PubMed]

86. Jansson, P.E.; Lindberg, B.; Sandford, P.A. Structural studies of gellan gum, an extracellular polysaccharide elaborated by Pseudomonas elodea. Carbohydr. Res. 1983, 124, 135-139. [CrossRef]

87. Koivisto, J.T.; Joki, T.; Parraga, J.E.; Paakkonen, R.; Yla-Outinen, L.; Salonen, L.; Jonkkari, I.; Peltola, M.; Ihalainen, T.O.; Narkilahti, S.; et al. Bioamine-crosslinked gellan gum hydrogel for neural tissue engineering. Biomed. Mater. 2017, 12, 025014. [CrossRef]

88. Slaughter, B.V.; Khurshid, S.S.; Fisher, O.Z.; Khademhosseini, A.; Peppas, N.A. Hydrogels in regenerative medicine. Adv. Mater. 2009, 21, 3307-3329. [CrossRef]

89. Morgelin, M.; Heinegard, D.; Engel, J.; Paulsson, M. The cartilage proteoglycan aggregate: Assembly through combined protein-carbohydrate and protein-protein interactions. Biophys. Chem. 1994, 50, 113-128. [CrossRef]

90. Nettles, D.L.; Vail, T.P.; Morgan, M.T.; Grinstaff, M.W.; Setton, L.A. Photocrosslinkable hyaluronan as a scaffold for articular cartilage repair. Ann. Biomed. Eng. 2004, 32, 391-397. [CrossRef]

91. Chung, C.; Mesa, J.; Randolph, M.A.; Yaremchuk, M.; Burdick, J.A. Influence of gel properties on neocartilage formation by auricular chondrocytes photoencapsulated in hyaluronic acid networks. J. Biomed. Mater. Res. A 2006, 77, 518-525. [CrossRef]

92. Lee, J.; Lee, S.H.; Kim, B.S.; Cho, Y.S.; Park, Y. Development and Evaluation of Hyaluronic Acid-Based Hybrid Bio-Ink for Tissue Regeneration. Tissue Eng. Regen. Med. 2018, 15, 761-769. [CrossRef] [PubMed]

93. San Juan, A.; Hlawaty, H.; Chaubet, F.; Letourneur, D.; Feldman, L.J. Cationized pullulan 3D matrices as new materials for gene transfer. J. Biomed. Mater. Res. A 2007, 82, 354-362. [CrossRef] [PubMed] 
94. Leathers, T.D. Biotechnological production and applications of pullulan. Appl. Microbiol. Biotechnol. 2003, 62, 468-473. [CrossRef] [PubMed]

95. Luca, A.; Maier, V.; Maier, S.S.; Butnaru, M.; Danu, M.; Ibanescu, C.; Pinteala, M.; Popa, M. Biomacromolecular-based ioniccovalent hydrogels for cell encapsulation: The atelocollagen-Oxidized polysaccharides couples. Carbohydr. Polym. 2017, 169, 366-375. [CrossRef] [PubMed]

96. Mienaltowski, M.J.; Birk, D.E. Structure, physiology, and biochemistry of collagens. Adv. Exp. Med. Biol. 2014, 802, 5-29. [CrossRef] [PubMed]

97. Dong, C.; Lv, Y. Application of Collagen Scaffold in Tissue Engineering: Recent Advances and New Perspectives. Polymers 2016, 8, 42. [CrossRef]

98. Kuo, K.C.; Lin, R.Z.; Tien, H.W.; Wu, P.Y.; Li, Y.C.; Melero-Martin, J.M.; Chen, Y.C. Bioengineering vascularized tissue constructs using an injectable cell-laden enzymatically crosslinked collagen hydrogel derived from dermal extracellular matrix. Acta Biomater. 2015, 27, 151-166. [CrossRef]

99. Rosenbloom, J. Elastin: Relation of protein and gene structure to disease. Lab. Investig. 1984, 51, 605-623.

100. Ozsvar, J.; Mithieux, S.M.; Wang, R.; Weiss, A.S. Elastin-based biomaterials and mesenchymal stem cells. Biomater. Sci. 2015, 3 , 800-809. [CrossRef]

101. Engler, A.J.; Sen, S.; Sweeney, H.L.; Discher, D.E. Matrix elasticity directs stem cell lineage specification. Cell 2006, 126, 677-689. [CrossRef]

102. Gasperini, L.; Mano, J.F.; Reis, R.L. Natural polymers for the microencapsulation of cells. J. R. Soc. Interface 2014, $11,20140817$. [CrossRef]

103. Bian, L.; Hou, C.; Tous, E.; Rai, R.; Mauck, R.L.; Burdick, J.A. The influence of hyaluronic acid hydrogel crosslinking density and macromolecular diffusivity on human MSC chondrogenesis and hypertrophy. Biomaterials 2013, 34, 413-421. [CrossRef] [PubMed]

104. Martens, P.J.; Bryant, S.J.; Anseth, K.S. Tailoring the degradation of hydrogels formed from multivinyl poly(ethylene glycol) and poly(vinyl alcohol) macromers for cartilage tissue engineering. Biomacromolecules 2003, 4, 283-292. [CrossRef] [PubMed]

105. Zhu, D.; Wang, H.; Trinh, P.; Heilshorn, S.C.; Yang, F. Elastin-like protein-hyaluronic acid (ELP-HA) hydrogels with decoupled mechanical and biochemical cues for cartilage regeneration. Biomaterials 2017, 127, 132-140. [CrossRef] [PubMed]

106. Wang, H.; Zhu, D.; Paul, A.; Cai, L.; Enejder, A.; Yang, F.; Heilshorn, S.C. Covalently Adaptable Elastin-Like Protein-Hyaluronic Acid (ELP-HA) Hybrid Hydrogels with Secondary Thermoresponsive Crosslinking for Injectable Stem Cell Delivery. Adv. Funct. Mater. 2017, 27. [CrossRef]

107. Van Den Bulcke, A.I.; Bogdanov, B.; De Rooze, N.; Schacht, E.H.; Cornelissen, M.; Berghmans, H. Structural and rheological properties of methacrylamide modified gelatin hydrogels. Biomacromolecules 2000, 1, 31-38. [CrossRef]

108. Tzouanas, S.N.; Ekenseair, A.K.; Kasper, F.K.; Mikos, A.G. Mesenchymal stem cell and gelatin microparticle encapsulation in thermally and chemically gelling injectable hydrogels for tissue engineering. J. Biomed. Mater. Res. A 2014, 102, 1222-1230. [CrossRef]

109. Aparnathi, M.K.; Patel, J.S. Biodegradable Gelatin Methacrylate Gel as a Potential Scaffold for Bone Tissue Engineering of Canine Adipose-Derived Stem Cells. J. Stem Cells 2016, 11, 111-119.

110. Sung, B.; Krieger, J.; Yu, B.; Kim, M.H. Colloidal gelatin microgels with tunable elasticity support the viability and differentiation of mesenchymal stem cells under pro-inflammatory conditions. J. Biomed. Mater. Res. A 2018, 106, 2753-2761. [CrossRef]

111. Bragulla, H.H.; Homberger, D.G. Structure and functions of keratin proteins in simple, stratified, keratinized and cornified epithelia. J. Anat. 2009, 214, 516-559. [CrossRef]

112. Barati, D.; Kader, S.; Pajoum Shariati, S.R.; Moeinzadeh, S.; Sawyer, R.H.; Jabbari, E. Synthesis and Characterization of PhotoCross-Linkable Keratin Hydrogels for Stem Cell Encapsulation. Biomacromolecules 2017, 18, 398-412. [CrossRef] [PubMed]

113. Vepari, C.; Kaplan, D.L. Silk as a Biomaterial. Prog. Polym. Sci. 2007, 32, 991-1007. [CrossRef] [PubMed]

114. Patil, S.; Singh, N. Silk fibroin-alginate based beads for human mesenchymal stem cell differentiation in 3D. Biomater. Sci. 2019, 7, 4687-4697. [CrossRef] [PubMed]

115. Hasturk, O.; Jordan, K.E.; Choi, J.; Kaplan, D.L. Enzymatically crosslinked silk and silk-gelatin hydrogels with tunable gelation kinetics, mechanical properties and bioactivity for cell culture and encapsulation. Biomaterials 2020, 232, 119720. [CrossRef] [PubMed]

116. Schmolka, I.R. Artificial skin. I. Preparation and properties of pluronic F-127 gels for treatment of burns. J. Biomed. Mater. Res. 1972, 6, 571-582. [CrossRef] [PubMed]

117. Wagner, M.A.; Marks, W.H.; Bhatia, S.K. Hydrogel encapsulation to improve cell viability during syringe needle flow. J. Long. Term Eff. Med. Implants 2014, 24, 151-162. [CrossRef] [PubMed]

118. Choi, J.H.; Choi, O.K.; Lee, J.; Noh, J.; Lee, S.; Park, A.; Rim, M.A.; Reis, R.L.; Khang, G. Evaluation of double network hydrogel of poloxamer-heparin/gellan gum for bone marrow stem cells delivery carrier. Colloids Surf. B. Biointerfaces 2019, 181, 879-889. [CrossRef]

119. Harris, J.M. Introduction to biomedical and biotechnical applications of polyethylene glycol. Am. Chem. Soc. Polym. Prepr. Div. Polym. Chem. 1997, 38, 520-521.

120. Choe, G.; Park, J.; Park, H.; Lee, J.Y. Hydrogel Biomaterials for Stem Cell Microencapsulation. Polymers 2018, 10, 997. [CrossRef] 
121. Li, F.; Truong, V.X.; Thissen, H.; Frith, J.E.; Forsythe, J.S. Microfluidic Encapsulation of Human Mesenchymal Stem Cells for Articular Cartilage Tissue Regeneration. ACS Appl. Mater. Interfaces 2017, 9, 8589-8601. [CrossRef]

122. Hunckler, M.D.; Medina, J.D.; Coronel, M.M.; Weaver, J.D.; Stabler, C.L.; Garcia, A.J. Linkage Groups within Thiol-Ene Photoclickable PEG Hydrogels Control In Vivo Stability. Adv. Healthc. Mater. 2019, 8, e1900371. [CrossRef] [PubMed]

123. Cruz-Acuna, R.; Quiros, M.; Huang, S.; Siuda, D.; Spence, J.R.; Nusrat, A.; Garcia, A.J. PEG-4MAL hydrogels for human organoid generation, culture, and in vivo delivery. Nat. Protoc. 2018, 13, 2102-2119. [CrossRef] [PubMed]

124. Schild, H.G. Poly(N-isopropylacrylamide): Experiment, theory and application. Prog. Polym. Sci. 1992, 17, 163-249. [CrossRef]

125. Ekerdt, B.L.; Fuentes, C.M.; Lei, Y.; Adil, M.M.; Ramasubramanian, A.; Segalman, R.A.; Schaffer, D.V. Thermoreversible Hyaluronic Acid-PNIPAAm Hydrogel Systems for 3D Stem Cell Culture. Adv. Healthc. Mater. 2018, 7, e1800225. [CrossRef]

126. de Vos, P.; Lazarjani, H.A.; Poncelet, D.; Faas, M.M. Polymers in cell encapsulation from an enveloped cell perspective. Adv. Drug Deliv. Rev. 2014, 67-68, 15-34. [CrossRef]

127. Vrana, N.E.; O’Grady, A.; Kay, E.; Cahill, P.A.; McGuinness, G.B. Cell encapsulation within PVA-based hydrogels via freezethawing: A one-step scaffold formation and cell storage technique. J. Tissue Eng. Regen. Med. 2009, 3, 567-572. [CrossRef]

128. Qi, Z.; Shen, Y.; Yanai, G.; Yang, K.; Shirouzu, Y.; Hiura, A.; Sumi, S. The in vivo performance of polyvinyl alcohol macroencapsulated islets. Biomaterials 2010, 31, 4026-4031. [CrossRef]

129. Dulieu, C.; Bazile, D. Influence of lipid nanocapsules composition on their aptness to freeze-drying. Pharm. Res. 2005, 22, 285-292. [CrossRef]

130. Qi, M.; Gu, Y.; Sakata, N.; Kim, D.; Shirouzu, Y.; Yamamoto, C.; Hiura, A.; Sumi, S.; Inoue, K. PVA hydrogel sheet macroencapsulation for the bioartificial pancreas. Biomaterials 2004, 25, 5885-5892. [CrossRef]

131. Burczak, K.; Gamian, E.; Kochman, A. Long-term in vivo performance and biocompatibility of poly(vinyl alcohol) hydrogel macrocapsules for hybrid-type artificial pancreas. Biomaterials 1996, 17, 2351-2356. [CrossRef]

132. Oda, H.; Konno, T.; Ishihara, K. Efficient differentiation of stem cells encapsulated in a cytocompatible phospholipid polymer hydrogel with tunable physical properties. Biomaterials 2015, 56, 86-91. [CrossRef] [PubMed]

133. Zhang, W.; Zhao, S.; Rao, W.; Snyder, J.; Choi, J.K.; Wang, J.; Khan, I.A.; Saleh, N.B.; Mohler, P.J.; Yu, J.; et al. A Novel Core-Shell Microcapsule for Encapsulation and 3D Culture of Embryonic Stem Cells. J. Mater. Chem. B 2013, 2013, 1002-1009. [CrossRef] [PubMed]

134. Mao, A.S.; Ozkale, B.; Shah, N.J.; Vining, K.H.; Descombes, T.; Zhang, L.; Tringides, C.M.; Wong, S.W.; Shin, J.W.; Scadden, D.T.; et al. Programmable microencapsulation for enhanced mesenchymal stem cell persistence and immunomodulation. Proc. Natl. Acad. Sci. USA 2019, 116, 15392-15397. [CrossRef] [PubMed]

135. Ryan, A.E.; Lohan, P.; O’Flynn, L.; Treacy, O.; Chen, X.; Coleman, C.; Shaw, G.; Murphy, M.; Barry, F.; Griffin, M.D.; et al. Chondrogenic differentiation increases antidonor immune response to allogeneic mesenchymal stem cell transplantation. Mol. Ther. 2014, 22, 655-667. [CrossRef] [PubMed]

136. Saldana, L.; Bensiamar, F.; Valles, G.; Mancebo, F.J.; Garcia-Rey, E.; Vilaboa, N. Immunoregulatory potential of mesenchymal stem cells following activation by macrophage-derived soluble factors. Stem Cell. Res. Ther. 2019, 10, 58. [CrossRef] [PubMed]

137. Swartzlander, M.D.; Blakney, A.K.; Amer, L.D.; Hankenson, K.D.; Kyriakides, T.R.; Bryant, S.J. Immunomodulation by mesenchymal stem cells combats the foreign body response to cell-laden synthetic hydrogels. Biomaterials 2015, 41, 79-88. [CrossRef] [PubMed]

138. Leijs, M.J.; Villafuertes, E.; Haeck, J.C.; Koevoet, W.J.; Fernandez-Gutierrez, B.; Hoogduijn, M.J.; Verhaar, J.A.; Bernsen, M.R.; van Buul, G.M.; van Osch, G.J. Encapsulation of allogeneic mesenchymal stem cells in alginate extends local presence and therapeutic function. Eur. Cell Mater. 2017, 33, 43-58. [CrossRef]

139. Dong, Y.; Cui, M.; Qu, J.; Wang, X.; Kwon, S.H.; Barrera, J.; Elvassore, N.; Gurtner, G.C. Conformable hyaluronic acid hydrogel delivers adipose-derived stem cells and promotes regeneration of burn injury. Acta Biomater. 2020, 108, 56-66. [CrossRef]

140. Khatab, S.; Leijs, M.J.; van Buul, G.; Haeck, J.; Kops, N.; Nieboer, M.; Bos, P.K.; Verhaar, J.A.N.; Bernsen, M.; van Osch, G. MSC encapsulation in alginate microcapsules prolongs survival after intra-articular injection, a longitudinal in vivo cell and bead integrity tracking study. Cell. Biol. Toxicol. 2020. [CrossRef]

141. Chen, Y.; Li, C.; Li, C.; Chen, J.; Li, Y.; Xie, H.; Lin, C.; Fan, M.; Guo, Y.; Gao, E.; et al. Tailorable Hydrogel Improves Retention and Cardioprotection of Intramyocardial Transplanted Mesenchymal Stem Cells for the Treatment of Acute Myocardial Infarction in Mice. J. Am. Heart Assoc. 2020, 9, e013784. [CrossRef]

142. Ho, S.S.; Vollmer, N.L.; Refaat, M.I.; Jeon, O.; Alsberg, E.; Lee, M.A.; Leach, J.K. Bone Morphogenetic Protein-2 Promotes Human Mesenchymal Stem Cell Survival and Resultant Bone Formation When Entrapped in Photocrosslinked Alginate Hydrogels. Adv. Healthc. Mater. 2016, 5, 2501-2509. [CrossRef] [PubMed]

143. Hyzy, S.L.; Olivares-Navarrete, R.; Schwartz, Z.; Boyan, B.D. BMP2 induces osteoblast apoptosis in a maturation state and noggin-dependent manner. J. Cell. Biochem. 2012, 113, 3236-3245. [CrossRef] [PubMed]

144. de Vries-van Melle, M.L.; Tihaya, M.S.; Kops, N.; Koevoet, W.J.; Murphy, J.M.; Verhaar, J.A.; Alini, M.; Eglin, D.; van Osch, G.J. Chondrogenic differentiation of human bone marrow-derived mesenchymal stem cells in a simulated osteochondral environment is hydrogel dependent. Eur. Cell Mater. 2014, 27, 112-123; discussion 123. [CrossRef] [PubMed]

145. Li, H.; Zheng, J.; Wang, H.; Becker, M.L.; Leipzig, N.D. Neural stem cell encapsulation and differentiation in strain promoted crosslinked polyethylene glycol-based hydrogels. J. Biomater. Appl. 2018, 32, 1222-1230. [CrossRef] 
146. Hung, B.P.; Harvestine, J.N.; Saiz, A.M.; Gonzalez-Fernandez, T.; Sahar, D.E.; Weiss, M.L.; Leach, J.K. Defining hydrogel properties to instruct lineage- and cell-specific mesenchymal differentiation. Biomaterials 2019, 189, 1-10. [CrossRef]

147. Prestwich, G.D. Engineering a clinically-useful matrix for cell therapy. Organogenesis 2008, 4, 42-47. [CrossRef]

148. Aguado, B.A.; Mulyasasmita, W.; Su, J.; Lampe, K.J.; Heilshorn, S.C. Improving viability of stem cells during syringe needle flow through the design of hydrogel cell carriers. Tissue Eng. Part A 2012, 18, 806-815. [CrossRef]

149. Foster, A.A.; Dewi, R.E.; Cai, L.; Hou, L.; Strassberg, Z.; Alcazar, C.A.; Heilshorn, S.C.; Huang, N.F. Protein-engineered hydrogels enhance the survival of induced pluripotent stem cell-derived endothelial cells for treatment of peripheral arterial disease. Biomater. Sci. 2018, 6, 614-622. [CrossRef]

150. Khetan, S.; Corey, O. Maintenance of stem cell viability and differentiation potential following cryopreservation within 3dimensional hyaluronic acid hydrogels. Cryobiology 2019, 90, 83-88. [CrossRef]

151. Zhao, G.; Liu, X.; Zhu, K.; He, X. Hydrogel Encapsulation Facilitates Rapid-Cooling Cryopreservation of Stem Cell-Laden Core-Shell Microcapsules as Cell-Biomaterial Constructs. Adv. Healthc. Mater. 2017, 6. [CrossRef]

152. Huang, H.; Choi, J.K.; Rao, W.; Zhao, S.; Agarwal, P.; Zhao, G.; He, X. Alginate Hydrogel Microencapsulation Inhibits Devitrification and Enables Large-Volume Low-CPA Cell Vitrification. Adv. Funct. Mater. 2015, 25, 6839-6850. [CrossRef] [PubMed]

153. Sambu, S.; Xu, X.; Schiffer, H.A.; Cui, Z.F.; Ye, H. RGDS-fuctionalized alginates improve the survival rate of encapsulated embryonic stem cells during cryopreservation. Cryo Lett. 2011, 32, 389-401.

154. Pravdyuk, A.I.; Petrenko, Y.A.; Fuller, B.J.; Petrenko, A.Y. Cryopreservation of alginate encapsulated mesenchymal stromal cells. Cryobiology 2013, 66, 215-222. [CrossRef] [PubMed]

155. Ashimova, A.; Yegorov, S.; Negmetzhanov, B.; Hortelano, G. Cell Encapsulation within Alginate Microcapsules: Immunological Challenges and Outlook. Front. Bioeng. Biotechnol. 2019, 7, 380. [CrossRef]

156. Lopez-Mendez, T.B.; Santos-Vizcaino, E.; Pedraz, J.L.; Hernandez, R.M.; Orive, G. Cell microencapsulation technologies for sustained drug delivery: Clinical trials and companies. Drug Discov. Today 2020. [CrossRef]

157. Heile, A.; Brinker, T. Clinical translation of stem cell therapy in traumatic brain injury: The potential of encapsulated mesenchymal cell biodelivery of glucagon-like peptide-1. Dialogues Clin. Neurosci. 2011, 13, 279-286. [CrossRef]

158. CellMed, A. GLP-1 CellBeads ${ }^{\circledR}$ for the Treatment of Stroke Patients with Space-Occupying Intracerebral Hemorrhage. NCT01298830. Available online: http:/ / www.clinicaltrials.gov (accessed on 13 May 2016). 